\title{
Contribución al catálogo del pintor e ilustrador John Vanderbank: seis nuevos óleos con escenas de El Quijote en el Museo de Pontevedra
}

\author{
MARÍA ÁNgeles TILVE JAR*
}

En 1738 se culminó en los prestigiosos talleres londinenses de los hermanos J. y R. Tonson una excelente edición, en cuatro tomos y en español, de El Quijote de Miguel de Cervantes ${ }^{1}$. Se trata de la primera edición de lujo de la obra que a partir de entonces será reconocida como un clásico. Realizada en cuarto mayor, con márgenes amplios y cuidadísima impresión, está ilustrada con sesenta y nueve estampas originales que no solo marcan un hito en la creación de la iconografía quijotesca sino que consolidan una nueva y culta lectura de la novela que, abandonando el carácter meramente humorístico y burlesco, se convierte en sátira moral.

La publicación, dedicada a la Condesa de Montijo, Antes Embaxadora en esta Corte de la Gran Bretaña ${ }^{2}$, y acompañada de una biografía firmada por Gregorio Mayáns y Siscar, se debe a la iniciativa del político británico John Carteret (16901763), barón de Carteret y conde de Granville. Miembro de la Cámara de los Lores desde 1711, Carteret, ferviente defensor de la dinastía alemana de los Hannover y muy cercano a la familia real, parece que deseaba agradar con ello a la cultivada Princesa de Gales, la futura reina Carolina ${ }^{3}$, una apasionada de los libros que lamentaba no poder encontrar una edición de la novela digna de ser

* Museo de Pontevedra.

1. Vida y hechos del ingenioso hidalgo Don Quixote de la Mancha, London: J.\& R. Tonson, 1738.

2. Dña. Dominga Fernández de Córdoba y Guzmán era la esposa del V conde de Montijo, D. Cristóbal Gregorio Portocarrero y Funes de Villalpando (1692-1763), Embajador de España en Londres entre 1732 y 1735. Parece ser que fue la intervención directa de los Condes de Montijo la que posibilitó el contacto entre Lord Carteret y el polígrafo valenciano Gregorio Mayáns y Siscar (1699-1781) para realizar el encargo de la primera biografía de Miguel de Cervantes (Astrana Marín, 1948 [2003]: I, IV, V, X-X).

3. Carolina de Brandeburgo-Ansbach (1683-1737), casada en 1705 con Jorge II, Rey de Gran Bretaña e Irlanda y elector de Hannover (1683-1760), accedió al trono el 11 de junio de 1727. 
incluida en su famosa biblioteca (Meixell, 2005: 59-82). El inicio del proyecto de Lord Carteret se sitúa en los primeros años de la década de 1720. Sin embargo, la complejidad de la empresa, así como la carrera política del comitente que será Lugarteniente de Irlanda de 1724 a 1730, provocarán sucesivas demoras que retrasarán la publicación definitiva de la obra hasta 1738, un año después del fallecimiento de la Reina (Lucía Megías, 2005: 175-215; 2006: 315-338).

Lord Carteret, miembro destacado del antiguo Partido Liberal, Whig, formado por aristócratas, grandes terratenientes y comerciantes londinenses que se oponían a las pretensiones monárquicas de los Estuardo y defendían los derechos del Parlamento, deseaba una edición de El Quijote que, en consonancia con sus ideales, valorase la ironía discreta y la sátira benévola por encima de aquellos aspectos que podían parecer ridículos u ofensivos. Para llevar a cabo este propósito se valdrá de un íntimo amigo, el pensador John Oldfield, quien no sólo establecerá el programa iconográfico de la obra sino que también escribirá un ideario estético que, con el título de Advertencias, se editará al inicio de la misma (Oldfield, 1738: I-VIII). En este texto, en el que Oldfield se muestra muy cercano a las teorías de Jonathan Richardson en Theory of Painting (1715), reivindica el papel expresivo de las estampas que dejan de ser exclusivamente un adorno editorial para, siguiendo un estricto programa y con un lenguaje propio, destacar aquellos episodios del texto que interesaban a una determinada lectura y una mejor comprensión de la obra:

Aunque las Estampas que se ponen en los Libros, casi siempre se estiman como unos meros adornos, y por la mayor parte están compuestos de manera que parecen de poca mayor importancia que los otros pulimentos de la encuadernación, y únicamente sirven de divertimiento a los que se pagan de solar galanuras, sin embargo las Estampas pueden servir a otro fin más elevado, representando y dando luz a muchas cosas, las cuales por medio de las palabras no se pueden expresar tan perfectamente (Oldfield, 1738: II).

En 1723 el proyecto, que Lord Carteret subvencionará con la elevada cantidad de 1.200 libras esterlinas, ya estaba en marcha. De la impresión de la obra se encargará la editorial londinense de Jacob y Richard Tonson, fundada en 1697, que se había especializado en la edición de obras magníficamente ilustradas de algunos de los grandes autores ingleses como Milton, Dryden o Shakespeare. En cuanto a los dibujantes y grabadores, se contará con habituales ilustradores de la editorial, como son los pintores John Vanderbank, William Hogarth y William Kent, y los grabadores George Vertue, Gerard Vandergucht y Claude du Bosc (Lucía Megías, 2006: 318-319).

Realmente, será el pintor John Vanderbank, como excelente dibujante, quien, entre 1723 y 1729, lleve el peso de la creación de las imágenes de la publicación ya que a él se debe mayoritariamente el diseño y dibujo del conjunto de estampas que, grabadas al aguafuerte, la acompañan ${ }^{4}$. De hecho,

4. Las imágenes de las estampas son accesibles en <http://www.qbi2005.com/ wfrmMosaico. aspx?irc $=3 \& \operatorname{irclD}=0111>$ y $<$ http://www.csdl.tamu.edu:8080/dqiDisplayInterface/doSearchImages . jsp?id $=1513 \&$ page $=1 \&$ orderBy $=1>$ 
tanto el frontispicio como sesenta y siete de las láminas, que la ilustran a toda página, llevan su firma. Otra, la n. ${ }^{\circ} 3$, que muestra la llegada de D. Quijote a la venta (I, cap. 2), aparecerá como anónima, aunque sabemos que el dibujo es también original de Vanderbank y el grabado, atribuido a William Hogarth (1697-1764), constituye el único vestigio de la participación de este autor vinculado en un primer momento al proyecto y que, finalmente, fue descartado de la obra por no ajustarse a los planteamientos marcados por Oldfield (Lucía Megías, 2006: 339, 456-466). Únicamente la imagen que reproduce el retrato de Cervantes, que acompaña la biografía firmada por Mayáns y Siscar, será totalmente ajena a su mano, siendo su autor William Kent, que la firma en 1730 (Lucía Megías, 2005: 183-185; 2006: 320-327).

No extraña que Vanderbank fuese el elegido para ilustrar los diferentes episodios de la lujosa edición promovida por Carteret ya que, además de su demostrada capacidad técnica, el artista manifestaba una clara coincidencia con su filosofía neoclásica, no en vano se había formado en las ideas de valoración de la pintura como nuevo lenguaje expresivo con Jonathan Richardson, fuente directa de Oldfield, el teórico de la obra.

Nacido en Londres el 9 de septiembre de 1694, en el seno de una prestigiosa familia de artistas, John Vanderbank era el primogénito del homónimo jefe de tejedores de la Manufactura de tapices del Soho londinense, de origen holandés aunque parisino de nacimiento, junto al que se inició artísticamente. Posteriormente, el joven Vanderbank completará su formación con dos importantes pintores de retratos, el citado Jonathan Richardson (1665-1745) y, desde 1711 hasta 1718, con Sir Godfrey Kneller (1646-1723) en la Academia Thornhill de James Street, en la que coincide e intima con el pintor francés Louis Cheron (1660-1725). En 1720, conjuntamente con Cheron, funda su propia academia en St. Martin's Lane, iniciativa de corta duración pero de gran influencia en la profesionalización del arte británico, que constituye el precedente de la Royal Academy. Desde las clases de dibujo de St. Martin, a las que asistirán artistas como Hogarth y Highmore, se difunde el rococó y las nuevas ideas estéticas en Inglaterra. Sin embargo, pronto la vida disoluta y bohemia de John Vanderbank hace mella en el proyecto. A pesar de que a la muerte de su padre, en 1717, había heredado una buena posición económica, el juego, el alcohol y los excesos de una vida apasionada y libertina le arruinan en muy poco tiempo. Las deudas le acucian y en 1724, para evitar entrar en prisión, debe huir durante seis meses a Francia. Este hecho, junto con la muerte de Cheron, provocará el cierre de la pionera academia que, posteriormente, en 1735, será restablecida por su alumno William Hogarth (Hammelmann, 1968: 289-293, 297-298; Waterhouse, 1969: 91, 114, 123-125, 128, 135-137, 139, 149, 255, 257-259, 270, 372; Einberg y Egerton, 1988: 228-231).

Esta forma de vida licenciosa y desenfrenada de Vanderbank acabará indudablemente perjudicando su carrera y, ya en su tiempo, el grabador y anticuario George Vertue (1684-1756), con el que comparte trabajos en la edición del Quijote de 1738, afirmaba: Solo su intemperancia le impidió ser el mejor 
retratista de su generación ${ }^{5}$ [Vertue, (1849): 676; 1750 (ed. 1934): 44, 97-98]. Efectivamente, poseía una depurada técnica y, desde muy joven, gozaba de un merecido prestigio. Entre sus obras iniciales destacan retratos de aristócratas y personalidades célebres del momento como Charles Spencer, III Duque de Marlborough (1719, British Governement Art Collection), Isaac Newton (1725, Trinity College, Cambridge) o el rey Jorge I (1726, Castillo de Windsor, Berks, Col. Real); elegantes y aduladoras representaciones, a menudo paisajistas, en las que conscientemente muestra la influencia de Anton Van Dyck (1599-1641) ${ }^{6}$. También hacia 1720, siguiendo todavía pautas barrocas, realizó algunos trabajos de pintura decorativa, entre los que sobresale el diseño de una escalera realizada, posiblemente por encargo de la señora Rebeca Moyer, para el n. ${ }^{\circ} 11$ de Bedford Row (Londres) en la que desarrolla una enorme copia de las Bodas de Cupido y Psyche de Rafael, y en la que además incluyó un retrato ecuestre del rey Jorge I y una alegoría de las Artes y Britania en el techo (Paulson, 1992: 103; Cherry, Pevsner, 2002: 20, 310, fot. 37).

Además de trabajar en la ilustración de otros libros editados por los Tonson, como los de Racine (1723) y Plutarco (1724-1729), la producción de la serie de dibujos que sirven de base a las ilustraciones del Quijote para la edición de 1738 ocupará intensivamente a Vanderbank desde 1723 hasta 1729. El proceso creativo de los diseños para estas estampas quijotescas es bien conocido a través de tres series de dibujos originales, realizados en lápiz, tinta y aguada (Paulson, 1998: 204-205). En el British Museum de Londres se conserva un álbum que contiene dos grupos de diseños, uno de bosquejos preliminares bastante diferenciados de los dibujos definitivos y otro con estudios ya terminados ${ }^{7}$. La tercera y más numerosa de las series de dibujos, el último de los cuales está fechado el 22 de diciembre de 1729, se conserva actualmente en la Pierpont Morgan Library (The Morgan Library \& Museum) de Nueva York ${ }^{8}$ (Lucía Megías, 2005: 187).

5. Traducción propia.

6. El pintor flamenco Anton Van Dyck (1599-1641), retratista y pintor de cámara en la Corte de Carlos I de Inglaterra, fue determinante en la evolución de la pintura británica. Con un gran dominio técnico, sus detallistas, embellecidos y refinados retratos aristocráticos de cuerpo entero, de proporciones alargadas y a menudo de tamaño natural, sobre fondos de paisaje o con ricos cortinajes y columnas, así como los retratos ecuestres y de caza del monarca, crearán una tipología iconográfica muy seguida en Inglaterra en los siglos posteriores. Maestro del grabado, disciplina en la que se había iniciado en su juventud en el taller de Rubens, Van Dyck comprendió y aprovechó la importancia de la producción de estampas, no solo como fuente de beneficios suplementarios, sino también como medio de promocionar su obra. Ya en vida, su pintura será difundida a través de versiones realizadas al aguafuerte por él mismo y sus colaboradores y poco después de su muerte se publicó su Iconografía (1645), donde aparece estampada una extensa galería de personajes ilustres contemporáneos, una obra que será fundamental en la formación del gusto artístico británico y en la difusión del elegante estilo del artista en el conjunto de Europa. Después y hasta finales del siglo XVIII su influencia se multiplica a través de sucesivas ediciones de estampas realizadas a partir de sus pinturas por destacados grabadores flamencos (Luna, 1989: pp. 104-116; Depauw, Luitjen, 2003).

7. Véase <http://www.britishmuseum.org/research/collection_online/collection_object_details. aspx ? objectId=725292\&partId=1\&searchText=QUIXOTE\&page $=3>$

8. Los dibujos accesibles en $<$ http://www.themorgan.org/search/drawings/vanderbank $>$ 
El programa llevado a cabo por Vanderbank supone el nacimiento del modelo inglés, uno de los más amplios de toda la iconografía quijotesca, con el que se impone una nueva interpretación culta de la novela: la sátira didáctica (Lucía Megías, 2006: 215-378). Con esta lectura en clave neoclásica y moralizante, criticando los efectos perniciosos de la mala literatura y defendiendo un decoroso modelo de conducta, se abandona la recepción de la obra cervantina como libro de caballerías, la interpretación, cómica y de entretenimiento, que desde el s. XVII proponía el modelo iconográfico holandés (Lucía Megías, 2006: 191-247). Las sobrias imágenes del esquema inglés se apartan también de la visión paródica de ambientación cortesana, teatral y opulenta que proponía el modelo francés iniciado por Charles-Antoine Coypel (1694-1752) a partir de 1715 en sus diseños de cartones para tapices de la Real Fábrica de Gobelinos. Una exitosa iconografía que Coypel concreta en 1724 con la edición comercial de un juego de estampas sueltas de gran tamaño, grabadas por los maestros más importantes del momento, y que configura definitivamente en sus ilustraciones para la edición parisina del Quijote de 1732, publicación que, al amparo del predominio de la cultura francesa, tendría una amplísima difusión y repercusión en toda Europa (Lucía Megías, 2006: 249-313).

Los diseños para la edición londinense de 1738 realizados por John Vanderbank, siguiendo escrupulosamente las pautas neoclásicas y académicas marcadas por Lord Carteret y Oldfield, contribuyeron también a fijar plásticamente la iconografía de los protagonistas de la novela cervantina. La amplia experiencia del artista británico como pintor de retratos y su capacidad para captar la expresión humana se manifiestan en sus clasicistas composiciones, protagonizadas por personajes de sobria elegancia y vestidos a la moda inglesa, en las que tanto don Quijote, como el rústico Sancho Panza, se alejan de lo grotesco para mostrarse ennoblecidos y dotados de una serena dignidad. El artista muestra su habilidad para dotar a los diferentes personajes de una gran expresividad, especialmente en rostros y manos, logrando manifestar sus sentimientos y plasmar los momentos de diálogo entre ellos. Los discursos y las conversaciones se convierten en tema principal de muchos de los diseños del inglés, cuyas escenas muestran también un estrecho vínculo iconográfico con el texto que están ilustrando, con el momento elegido en un episodio concreto, llegando incluso a transformar en las imágenes un párrafo determinado para ofrecer esa nueva perspectiva culta de la obra (Lucía Megías, 2005: 192-215). Igualmente, con este fin, y aún sin afectar al humor del libro, excluye aquellos episodios que narran las situaciones más disparatadas o ridículas del personaje para, con un carácter épico, presentar a don Quijote como un heroico caballero que con nobleza e integridad se entrega a la defensa de su ideal, lo que compensa la insensatez y desvaríos de su locura.

De este modo, dignificando al personaje y su mundo, Vanderbank creará veintisiete ilustraciones para los cincuenta y dos capítulos de la primera parte de la novela de Cervantes y cuarenta y una para los setenta y cuatro que componen la segunda parte de la misma, en las que no aparecen las represen- 
taciones más explícitas de la enajenación del personaje y con las que inicia su mitificación iconológica, contribuyendo a la creación del mito del Quijote (Schmidt, 1999: 47-50, 64-88). Algunos episodios aparecerán ilustrados con dos imágenes, como es el caso del capítulo 16 de la primera parte, y del 45, 60 y 62 de la segunda. También, en la segunda parte de la novela, los capítulos 32 y 69 serán ilustrados con tres láminas cada uno.

Esta cuidada y lujosa edición, en la que las estampas dejan de ser un mero complemento del texto, impone también un nuevo modelo editorial que triunfará en Inglaterra desde 1742, año en el que los Tonson editan la traducción inglesa del Quijote firmada por Charles Jarvis, The Life and Exploits of the ingenious gentleman Don Quixote de la Mancha, que será una de las más apreciadas y difundidas en las décadas siguientes ${ }^{9}$ (Lucía Megías, 2006: 347349). A través de la traducción de Jarvis que, reutilizando las planchas de las estampas será ilustrada con las imágenes creadas por Vanderbank, gozará de un éxito sin precedentes entre el público erudito e intelectual, la estructura narrativa y el sentido paródico del Quijote fascinará a los novelistas y autores de teatro británicos. Bajo la influencia de Jarvis y después de Smollet, quien realiza una nueva traducción para la edición de 1756, ilustrada con el mismo espíritu por Francis Hayman (1708-1776), surge un nuevo Quijote en el que la exaltación de los valores caballerescos y la idealización del modelo de conducta del protagonista, presentado como un héroe trágico, noble y digno, prevalecen sobre los aspectos más cómicos de la novela cervantina y la convierten en un arma ideológica, una herramienta moralizante, en manos de los ilustrados (Ardila, 2005: 254-259; Lucía, 2006: 350-351). Esta nueva lectura neoclásica, destinada a dignificar el carácter y acciones del protagonista, interpretada y representada visualmente a partir del cerrado programa diseñado por Vanderbank, supone el inicio de la mitificación icónica y cultural de El Quijote que comienza a consolidarse como referente literario y moral. Un nuevo criterio de lectura, que abrirá el camino a la interpretación simbólica de la obra y a la lectura romántica de la misma que elevará al personaje al nivel de mito universal (Close, 2005).

\section{LAS PINTURAS QUIJOTESCAS DE JOHN VANDERBANK}

En la década de 1730, John Vanderbank, una vez concluido el diseño de las estampas para la edición de El Quijote de los Tonson, continúa realizando numerosos retratos para la alta sociedad londinense, como los de Edward Wortley Montagu (1730, British Government Art Collection), Capitán mer-

9. Este modelo editorial de lujo no triunfará todavía en el resto de Europa, donde se tiende a realizar ediciones de menor tamaño y más económicas. En el caso de España, el texto cervantino se imprimía también en ediciones populares, de surtido, y el lujoso modelo británico constituirá el punto de partida de la edición de la Academia de 1780 (Blas y Matilla, 2003: 73-117; Lucía Megías, 2006: 379-431). 
cante con el cuadrante de Elton (Ca. 1730, National Maritime Museum, Greenwich), John Harvey (1732 British Government Art Collection), Anne y Mary Tonson (1734, Museum Sheffield), la Mujer de blanco (1736, Dulwich Picture Gallery), el de la Reina Carolina (1736, Duke of Richmond and Gordon) o el Joven de la familia Lee (1738, Tate Gallery). Sin embargo, su particular forma de vida le sume en un período de grave crisis financiera que, tras haber sido declarado en bancarrota en 1734, le lleva incluso a ingresar en prisión. Sin embargo, según las anotaciones de Vertue, por estos años y hasta su prematuro fallecimiento el 23 de diciembre de 1739, el artista contará con la ayuda de un rico protector que le proporcionará alojamiento en Hollis Street, cerca de Cavendish Square, a cambio de una serie de pinturas con escenas del Quijote (Vertue, [1849]: 676; 1750 [ed. 1934]: 44, 97-98).

En todas ellas John Vanderbank transcribe en pintura las diferentes escenas que había creado para las estampas de la edición londinense de los Tonson. Aunque, objetivamente, desconocemos quién fue el responsable del encargo de la serie de cuadros de temática quijotesca, el que estas fuesen realizadas antes de la publicación del libro en 1738 y, por lo tanto, de que sus ilustraciones fuesen conocidas por el público, así como el antes citado comentario de Vertue sobre la existencia de un adinerado mecenas que lo fomenta, nos hace pensar en la posibilidad de que fuese el propio Lord Carteret quien, apasionado por el tema y conocedor privilegiado del hasta entonces inédito trabajo de Vanderbank, le encargase la reproducción de sus aún desconocidos diseños para las estampas de la novela cervantina en una serie de pinturas al óleo. De hecho, el pintor seguía manteniendo una buena relación con el aristócrata para el que, a mediados de la década de 1730, realiza también algunos retratos, como los de sus hijas Louise y Grace (Ham House, Surrey) y uno colectivo de la familia Carteret en gran formato ${ }^{10}$.

Igualmente, como veremos, la existencia de varios cuadros que duplican con ligeros matices algunas de las escenas nos señala que quizás en sus últimos años el artista vislumbró el potencial de estas pinturas de temática quijotesca, y ante el entusiasmo creciente del público británico por la novela de Cervantes, al fin editada y comercializada en abril de 1738, se había decidió a explotar y capitalizar ese nuevo mercado con la venta de pequeños cuadros independientes, alguno de los cuales fue recogido en su estudio tras su fallecimiento en 1739 (Vertue, 1750 (ed. 1934): 97-98).

Son escasos los precedentes conocidos de obras que muestran al Quijote en pintura con anterioridad a las de John Vanderbank, siendo el pintor inglés uno de los pioneros en trascender el personaje de Cervantes del ámbito de la ilustración gráfica a un género independiente de pintura basada en textos literarios, que tendrá un gran auge posterior. Sobre El Quijote los antecedentes

10. Se encuentra documentada la venta de esta obra, un óleo sobre lienzo de 275 x $385 \mathrm{~cm}$, en la subasta londinense de Christie's del 10 de noviembre de 1995 (lote n. ${ }^{\circ} 10$, pág. 18 del catálogo). Véase <http://es.artprice.com/artista/29205/john-vanderbank/lote/pasado/1/Pintura/543156/group-portrait-john-carteret-1 st-earl-of-granville-with-his-family?iso3=EUR\&p=2\&unite_to $=\mathrm{cm}>$ 
en pintura se reducen a algunos ejemplos decorativos, como los 34 paneles con escenas de la novela que decoran el comedor del Chateau de Theverny que, atribuidos a Jean Mosnier (1600-1656), suelen datarse hacia 1642 (Lucía Megías, 2006: 133-143) ${ }^{11}$ y ya a finales del s. XVII, como asunto de algunos tapices realizados en Flandes e Inglaterra, como los tempranos cartones de Francis Poyntz (¿?-1685) que John Vanderbank pudo haber conocido a través de la vinculación de su padre con la Manufactura del Soho. Pero, aunque la concepción y el espíritu que mueve a ambos creadores sean totalmente diferentes, su precedente más directo es, indudablemente, el temprano y exitoso trabajo que desde 1715 realizaba el pintor francés Charles-Antoine Coypel en los ya citados cartones para los Gobelinos. Es a partir de estos momentos cuando la novela de Miguel de Cervantes y las aventuras de su atrayente protagonista comienza a ser reclamada como asunto pictórico por la aristocracia culta y, de hecho, las pinturas de Vanderbank serán contemporáneas de otras como las de la española Ana Meléndez Durazzo (1714-1760) que, interpretando a Coypel, inicia en 1730 una serie de miniaturas ${ }^{12}$, o las que el francés Charles-Josep Natoire (1700-1777) realiza en gran formato entre 1735 y 1744 (García Felguera, 2005: 155-171).

Del citado conjunto de escenas quijotescas realizadas al óleo por Vanderbank se conocen actualmente un considerable número de obras, sobre lienzo y sobre tabla, algunas de las cuales aparecen fechadas por el pintor entre 1730 y $1736^{13}$. En cuanto a los lienzos, además de dos adquiridos en 1913 por el Barón de Quinto ${ }^{14}$, descritos con los títulos de Don Quijote se

11. Sobre este importante conjunto, ejemplo del temprano éxito de la obra de Cervantes entre la nobleza francesa, José Manuel Lucía Megías aporta en su estudio importantes precisiones estilísticas e iconográficas y, además de descartar la tradicional atribución a María de Médicis como promotora del encargo y plantear sus dudas sobre la autoría de Jean Mosnier, revela que no puede seguir datándose la obra en su conjunto en torno a 1642 ya que, al menos algunos de los panneaux, muestran evidentes similitudes con las estampas de Charles Antoine Coypel, por lo que han de datarse con posterioridad a 1724 e incluso a 1732, cuando se imprime en París la exitosa primera edición del Quijote ilustrada por Coypel.

12. Actualmente se conservan de la artista de origen asturiano 12 miniaturas de esta temática en el Museo de Bellas Artes de Asturias (Díez, 2004: 84, 210, 281) y, relacionadas con estas, otras 21 en la Colección Eugenio Fontaneda en el Castillo de Ampudia (Palencia) (Fontaneda Berthet, León López, 2005). A la misma temática pertenecían también las miniaturas de un álbum que la artista ofreció en 1759, con motivo de su ingreso como Académica en la Real Academia de San Fernando, a Carlos III.

13. Además de las obras localizadas en instituciones públicas y colecciones privadas, las aportaciones bibliográficas que recogen diferentes subastas y ventas realizadas en el mercado inglés entre 1909 y 1985, han permitido rastrear la existencia y vicisitudes de un importante número de pinturas de temática quijotesca de Vanderbank (Causey, 1967: 38-39; Hammelmann, 1968: 289-293, 297-298; Ingamells, 1968: 763-767; Hammelmann, 1969: 3-15; Hammelmann, 1975: 81-82, 85; Einberg, 1987; Einberg y Egerton, 1988: 228-231).

14. José Muñoz, barón de Quinto, es un personaje de misteriosa biografía, que desde los años finales del siglo XIX ostenta este título nobiliario que había pertenecido a la Emperatriz Eugenia de Montijo y que esta, fallecida en 1920, le cede en vida (Ruiz i Quesada, Francesc, 2009-2011: 49, 53). Residente en París y con casa también en San Sebastián, el Barón de Quinto, poseedor de una gran fortuna, era un importante coleccionista de arte, interesado especialmente por la pintura renacentista y barroca. En 1905 vendió, tras un complejo proceso, una serie de siete obras de su colección, entre 
encuentra con la Princesa ${ }^{15}$ y El Compañero, ambos de 122,5 × 100,5 $\mathrm{cm}^{16}$, se encuentra documentada la existencia de otros cinco que reproducen las escenas correspondientes a las estampas 4, 42, 60 y $64^{17}$, así como la n. 9 que, con unas dimensiones de 127 x $102 \mathrm{~cm}$ y narrando el episodio de la Aparición de Marcela ante el cuerpo de Grisóstomo, se conserva

las que se encontraban cuadros de Goya, Sassoferrato, March y Dou, así como de Rosales y Corot, a la Junta de Museus de Barcelona (Boronat y Trill, 1999: 89, 92, 96-99,114, 201, 228-243, 261, 277 ; March, 2011: 70. 72). Posteriormente, en 1914, venderá también cuatro tablas atribuidas a Bartolomé Bermejo, pertenecientes al retablo de Santo Domingo de Silos, dos a la citada Junta de Museus y otras dos a Teresa Amatller, hoy conservadas en las colecciones del Museu Nacional d'Art de Catalunya y en el Institut Amatller d'Art Hispànic de Barcelona (Tormo y Monzó, 1926: 80-81; Boronat y Trill, 1999: 357, 411-412; Ruiz i Quesada, 2009-2011: 43). El Barón de Quinto fue también el promotor de la construcción del Teatro de Villarrobledo (Albacete), un destacado edificio de estilo modernista, que se inauguró en julio de 1916 (El Imparcial. Madrid, 31-7-1916, accesible en <http://hemerotecadigital.bne.es/issue.vm?id=0000 358310\&search=\&lang=es>). En 1917 el Barón será noticia en los periódicos nacionales y norteamericanos cuando pierda una importante parte de su colección en el gran incendio que destruyó el Ateneo de Santander. Entre las obras perdidas, que formaban parte de la exposición que se celebraba en el edificio, valoradas en más de 250.000 dólares, se encontraban, entre otras, Los discípulos de Emaús de Velázquez, un Retrato del Duque de Richmond de Van Dyck, Venus y Adonis de Tiziano y, también, una escena de El Quijote de Fragonard (La Época. Madrid, 8-1-1917, p. 2; 11-1-1917, p. 2, < http://hemerotecadigital.bne.es/issue.vm?id=0000867342\&search=\& lang $=\mathrm{es}>\mathrm{y}<\mathrm{http}: / /$ hemerotecadigital. bne.es/issue.vm?id=0000867404\&page $=2 \& \mathrm{search}=\% 22 \mathrm{Bar} \% \mathrm{C}$ 3\%B3n+de+Quinto\%22\&lang=es>; El Imparcial. Madrid, 11-1-1917, p. 4, accesible en <http://hemerotecadigital.bne.es/issue.vm? id $=0000365491 \&$ search $=\&$ lang $=$ es $>$. Dado lo extraño del siniestro serán detenidos los guardias de la exposición, acusados de anarquismo, y, después, el Barón recurrirá a las autoridades y a la prensa norteamericanas al sospechar que los cuadros habían sido en realidad robados y llevados a Estados Unidos para su venta (Chicago Livestock World, 15-2-1917, <http:// idnc.library.illinois.edu/cgi-bin/illinois? $\mathrm{a}=\mathrm{d} \& \mathrm{~d}=\mathrm{CLW} 19170215.2 .13>$; New York Herald, 15-2-1917, p. 2, accesible en <http://fultonhistory.com/Fulton.html>; San Francisco Chronicle, 15-2-1917, p. 8, $<$ http://www.newspapers.com /newspage/27335261/; Washington Post, 15-2-1917, p. 1, accesible en $<\mathrm{http}$ //newspaperarchive.com/us/district-of-columbia/washington/washington-Post/1917/02-15/>; Oxnard Daily Courier, 23-3-1917, p. 4, <http://newspaperarchive.com/us/california/oxnard/oxnarddaily-courier/1917/03-23/page-4>; Princeton Daily Democrat, 23-3-1917, p. 3, accesible en <http:// newspaperarchive.com/us/indiana/princeton/princeton-daily-democrat/1917/03-23/page-3>, Santa Ana Register, 23-3-1917, p. 2, accesible en <http://www.newspapers.com/ newspage/72255474/>).

15. Según este título podría tratarse de la versión de la estampa n. ${ }^{\circ} 19$, Aventura de la Princesa Micomicona (I, cap. 29), que, en el diseño de Vanderbank para la edición londinense de la novela, representa el momento en el que Micomicona se postra ante D. Quijote.

16. Los dos formaban parte del lote n. ${ }^{\circ} 118$ de la subasta de Christie's del 18 de marzo de 1913 (Einberg y Egerton, 1988: 228-231)

17. Se encuentra documentada la venta, en la subasta londinense de Sotheby's del 13 de mayo de 1920 y, posteriormente, en la realizada por Alice Sophie Heldmann, Puttick y Simpson en Worton Court, Isleworth, el 13 y14 de marzo de 1939, de los lienzos que desarrollan los episodios de las estampas, n. ${ }^{\circ}$ 4, Don Quijote es armado caballero por el mesonero (I, cap. 3); n. ${ }^{\circ}$ 9, Aparición de Marcela ante el cuerpo de Grisóstomo (I, cap. 14) y n. ${ }^{\circ}$ 64, que reproduce la segunda de las tres estampas que ilustran el capítulo del Encantamiento de Altisidora (II, cap. 69). Los otros dos, que versionan las estampas n. ${ }^{\circ} 60$, Don Quijote visita las galeras (II, cap. 63), y la n. ${ }^{\circ} 42$, Cuatro doncellas lavan la barba a Don Quijote (II, cap. 32), fueron adquiridos en Sotheby's, el 15 de marzo de 1967, por Marshall Spink (Einberg y Egerton, 1988: 228-231). Del episodio de la estampa n. ${ }^{\circ} 42$, que se corresponde con la segunda de las tres ilustraciones que en la edición de 1738 presenta el capítulo 32 de la segunda parte de la novela, titulado Bromas en casa de los duques, existe también una segunda réplica realizada por Vanderbank sobre tabla que, actualmente, se conserva en Marble Hill House, Twickenham, Richmond Middlesex. Véase en <http://www.marblehillsociety.org.uk/pages/2009/06/historical-researches.shtml >). 
actualmente en el Museo de Bellas Artes de Bilbao (García Felguera, 2005: 160-161).

Mucho más numerosas, en torno a cuarenta, son las versiones conocidas de las ilustraciones del Quijote que Vanderbank pintó sobre tablas de roble francés de pequeño formato. Estas, por sus reducidas y casi idénticas dimensiones $^{18}$, además de por su unidad estilística y formal, se presentan como cuadros de gabinete que, a la manera de los flamencos y holandeses, gozaban de gran éxito desde los años iniciales del siglo XVIII al amparo del nuevo interés surgido por la pintura y el coleccionismo entre la nobleza ilustrada europea. Buenos ejemplos de este conjunto de pinturas que reproducen diferentes estampas de la edición de 1738 son las que pueden contemplarse actualmente en la Tate Gallery de Londres (estampa 8) ${ }^{19}$, York Museums Trust (York Art Gallery) (estampa 21) ${ }^{20}$, Marble Hill House, Twickenham, Richmond Middlesex (estampas 42 y 63) ${ }^{21}$, Manchester Art Gallery (estampas 3 y 23$)^{22}$, The Huntington Library, Art Collections, and Botanical Gardens (San Marino, California) (estampas 12 y 44) ${ }^{23}$; Yale Centre for British Art (Hartford, Connecticut) (versión repetida de la estampa 44) ${ }^{24}$, así como en diversas colecciones particulares de Estados Unidos y Gran Bretaña, entre otras las vendidas por la Philip Mould Ltd. de Londres (estampa 53 y una versión

18. Se documentan dos grupos de obras, uno de ellos, el más numeroso con unas dimensiones en torno a 40,5 x $29 \mathrm{~cm}$ y un pequeño grupo de 40,5 x $39 \mathrm{~cm}$ aproximadamente.

19. Obra correspondiente al $\mathrm{n}^{\circ}$ de inventario T00937, en la que se reproduce la escena del Discurso de la Edad de Oro (I, cap. 11), de la que se conoce otra versión sobre tabla. Véase <http://www. tate.org.uk/art/artworks/vanderbank-don-quixote-addressing-the-goatherds-t00937>

20. Reproduce una segunda versión de la Aventura de los Cueros del vino (I, cap. 35), accesible en <http://www.yorkmuseumstrust.org.uk/collections/search/vanderbank>. Como veremos más adelante, se trata de una reinterpretación de una de las tablas que se encuentran actualmente en el Museo de Pontevedra.

21. La estampa 42 reproduce el episodio en el que Cuatro doncellas lavan la barba a Don Quijote (II, cap. 32) que se corresponde con la segunda de las estampas que, en la edición de 1738, ilustra el capítulo titulado Bromas en casa de los duques, escena de la que Vanderbank realizó también, como ya hemos visto, una segunda réplica sobre lienzo. La n. ${ }^{\circ} 63$ reinterpreta la primera de las tres estampas que ilustran el capítulo del Encantamiento de Altisidora (II, cap. 69), accesible en <http:// www.marblehillsociety.org.uk/pages/2009/ 06/historical-researches.shtml>

22. Reproducen la Llegada de Don Quijote a la venta (I, cap. 2), accesible en <http://www. manchestergalleries.org/the-collections/search-the-collection/display.php?EMUSESSID $=$ cf1 fce $3 \mathrm{cb} 82$ beea29cb3bfcebda69164\&irn $=7266>$ y El Padre de Zoraida descubre a su hija con el cautivo (I, cap. 41), <http://www.manchestergalleries.org/the-collections/search-thecollection/display. php?EMUSESSID $=$ cf1 fce3cb82beea29cb3bfcebda69164\&irn=7266>

23. Sancho contando los dientes de Don Quijote (I, cap. 18), <http://emuseum.huntington.org/ view/objects/asitem/search\$0040/0?t:state:flow=600ea3b6-672b-4267-9d92-0bc2f87101a5>, y Antes de hablar con la Duquesa, Sancho se asegura de que no hay nadie detrás de los tapices (II, cap. 33), $<$ http://emuseum.huntington.org/view/objects/asitem/search\$0040/0? t:state:flow=747238e 7-3555-4992b289-18444711093a>

24. Reinterpretación del episodio en el que Antes de hablar con la Duquesa, Sancho se asegura de que no hay nadie detrás de los tapices (II, cap. 33), reproducida en <http:/www.mystudios.com/ artgallery/J/John-Vanderbank/A-Scene-from-Don-Quixote-\%28Volume-II\%2C-Chapter-XXIII\%29. html $>$. La otra versión pintada sobre tabla de la escena, como hemos visto, se encuentra en The Huntington Library, Art Collections, and Botanical Gardens (San Marino, California), <http://emuseum.huntington.org/view/objects/asitem/search\$0040/0? t:state:flow=747238e7-3555-4992-b289-18444711093a> 
repetida e invertida de la 7$)^{25}$ y, en España, las cuatro de la Biblioteca del Cigarral del Carmen de Toledo (estampas 7, 15, 27 y 68) ${ }^{26}$.

Indudablemente, por sus evidentes similitudes formales y estilísticas, a esta serie en pequeño formato pertenecen también los seis óleos que actualmente posee el Museo de Pontevedra, en los que se interpretan las estampas 18, 21, $31,32,43$ y 51, que hasta la fecha permanecían inéditos y que constituyen el objeto de este estudio. Con ellos es posible ahora ampliar el catálogo de pequeñas tablas quijotescas de Vanderbank en el que, junto con algunas de escena no identificada, se encuentran localizadas y/o documentadas las que interpretan las estampas $3,7,8,11,12,15,18,19,21,23,27,31,32,33,35$, $37,38,42,43,44,45,46,47,51,53,57,58,63,65,67$ y 68, así como segundas versiones, realizadas igualmente al óleo sobre tablas de roble, que duplican las escenas de las estampas 7, 8, 21, 44, 51 y 53.

De las obras pertenecientes al Museo de Pontevedra, dos reproducen episodios comprendidos en la primera parte de la novela, publicada por Miguel de Cervantes en 1605: Encuentro con Dorotea en Sierra Morena (Cap. 28) y Aventura de los cueros de vino (Cap. 35). A la segunda parte, publicada en 1615, pertenecen las otras cuatro: Sansón Carrasco se ofrece para ser escudero de D. Quijote (Cap. 7); El encantamiento de Dulcinea (Cap. 10); Broma en casa de los Duques: Sancho sale corriendo del lugar del lavatorio de la barba (Cap. 32) y Sancho Panza tiene que defender su ínsula (Cap. 53). Todas ellas ingresaron en la Institución como depósito de José Fernandez López el 20 de febrero de 1961, realizando la entrega, en su nombre, Víctor Domínguez Borrajo, un intermediario artístico establecido en Madrid con el que frecuentemente trabajaba el importante coleccionista gallego ${ }^{27}$. Desde

25. El episodio correspondiente a la estampa 53 muestra una reinterpretación, con la composición invertida, del episodio del Torneo de D. Quijote y Tósilo (II, cap. 56). El que corresponde a la estampa 7 muestra a Sancho solicitando a D. Quijote el gobierno de alguna ínsula (I, cap. 10), versión de la que se localiza en la Biblioteca del Cigarral del Carmen (Toledo) y, con respecto a esta y a la estampa publicada en la edición de 1738, presenta la composición invertida. Ambas tablas aparecen reproducidas en $<$ http://www.historicalportraits.com/Gallery.asp $>$

26. Sancho solicitando a D. Quijote el gobierno de alguna insula (I, cap. 10); Aventura de los galeotes (I, cap. 22); Aventura de los disciplinantes (I, cap. 52) y Don Quijote hace testamento (II, cap. 74) (Krahe, 2003: 62- 63).

27. José Fernández López (Sarria-Lugo, 1904-Lugo, 1986), fue uno de los grandes empresarios españoles del siglo XX, fundador de algunas de las más importantes e innovadoras firmas de la economía gallega y nacional, como Zeltia (1939), Frilugo (1941), Transfesa (1943), Antibióticos S.A. (1949), Frigsa (1951), Cementos del Noroeste S.A. (1958) o Pescanova (1960). Estudió Derecho en Madrid, integrándose en los círculos republicanos y galleguistas llegando a formar parte, durante la Dictadura de Primo de Rivera, del grupo Mocedade Céltiga donde coincide con Fermín Fernández Penzol y Álvaro Gil Varela. Con el comienzo de la Guerra Civil sus empresas cárnicas fueron las principales abastecedoras del ejército franquista, lo que supondrá su despegue financiero y, pese a su ideología, una posición de fuerza en el Régimen, lo que le permitirá dar cobijo en su red de empresas a conocidos intelectuales y científicos gallegos represaliados (Carmona Badía (2006): 434-442). José Fernández López, que en 1950 colabora en la fundación de la Editorial Galaxia, poseía una amplia formación cultural y fuertes inquietudes artísticas que le llevarán a convertirse en un gran coleccionista de arte. En 1960 entra en contacto con el Museo de Pontevedra, convirtiéndose, desde entonces y hasta su muerte, en uno de los grandes mecenas de la entidad en la que, además de significativas 
1994 las obras son propiedad del Museo de Pontevedra al ser adquiridas con el conjunto de la colección Fernandez López a sus herederos.

En el momento del ingreso las tablas estaban, equivocadamente, adscritas a la escuela flamenca del s. XVIII y atribuidas a la autoría de un inédito pintor de nombre «Vanderbanle», y de este modo figuran en el asiento correspondiente del Libro de Registro General. Ese error en la atribución, que se mantuvo durante cincuenta años en el inventario y catálogo del Museo, vino determinado, evidentemente, por una inexacta lectura de las firmas que presentan cinco de las obras, dos de las cuales incluso presentan adheridas en sus marcos antiguas placas metálicas grabadas con ese nombre equivocado ${ }^{28}$. Una revisión de la colección efectuada en 2011, en la que se ha podido contar con el apoyo de las fundamentales aportaciones derivadas de los estudios publicados en torno a la conmemoración en 2005 del Cuarto Centenario de la publicación de la primera parte del Quijote, así como con los recursos digitales que recogen las diferentes ediciones y representaciones iconográficas de la obra cervantina ${ }^{29}$, me han permitido identificar correctamente a John Vanderbank como autor de este grupo de pinturas $^{30}$.

Desconocemos dónde fueron adquiridas estas obras por Fernández López ni su procedencia anterior, pero es posible que estas, como un buen número de las de la serie de Vanderbank, hubieran formado parte durante el siglo XIX de la colección del librero británico James Toovey ${ }^{31}$, pues a esa antigua co-

donaciones de piezas y aportaciones económicas, financia la construcción de uno de los edificios, el que lleva su nombre, y realiza constantes depósitos de obras relevantes. La particularidad de la gran colección Fernández López es su variedad, ya que, si bien en ella predomina la pintura, entre la que sobresalen las magníficas colecciones de los s. XV-XVI, bodegones y pintura española del s. XIX y comienzos del XX, comprende categorías tan diversas como la arqueología, la escultura, el mobiliario, la orfebrería y las artes decorativas. Además incorporó también destacados fondos documentales y bibliográficos. Fuera de Galicia, en Mérida, sede de algunas de sus industrias, ejerció también el mecenazgo, apoyando las excavaciones arqueológicas de la Alcazaba y la creación del laboratorio geológico-minero de Extremadura dirigido por Vicente Sos Baynat. La extensa colección de minerales, rocas y fósiles reunidas en el laboratorio, donadas en 1982, constituyen la base de la Geoemérita (Colección de Geología de Extremadura) que desde 2011 custodia el Museo Abierto de Mérida (MAM).

28. Las obras citadas son las correspondientes a N. ${ }^{\circ}$ Reg. 4.095 y 4.098.

29. Véanse entre otras: Lenagham (coord.), (2003); Urbina, Monroy, Furuta (2004); González Moreno, Urbina, Furuta, Deng (2005) [2006]; Lucía Megías (2005) y (2006); Torres Santo Domingo (coord.) (2005); Salvador Miguel, López Ríos (ed.) (2005) y en <http://www.qbi2005.com/; http:// www.centroestudioscervantinos.es>; <http://cervantes.tamu.edu/V2/CPI/variorum/index.htm; http:// www.uclm.es; http://cervantes.uah.es/>

30. En la actualidad las obras de John Vanderbank no se encuentran expuestas en las salas de la colección permanente del Museo de Pontevedra, aunque sí son accesibles al público a través de la web $<$ http:/catalogo.museo.depo.es/inweb/ficha.aspx?t=o\&id=26742>; $\quad<$ http://catalogo.museo.depo.es/inweb/ficha.aspx?t=o\&id=35552 $>$; $\quad<$ http://catalogo.museo.depo.es/inweb/ficha.aspx?t=o\&id=35554 $>$; $<$ http://catalogo. museo.depo.es/inweb/ficha.aspx?t=o\&id=35556>; $<$ http://catalogo.museo.depo.es/inweb/ficha.aspx?t=o\&id=35558 $>$; $<$ http://catalogo.museo.depo. es/inweb/ficha.aspx?t=o\&id=35559>

31. James Toovey (1814-1893) fue un señalado editor y librero londinense que destacó también como importante coleccionista. La compilación bibliográfica de James Toovey, que desde 1878 integró por compra la de Archibald Acheson, conde de Gosford (1806-1864), fue vendida por su hijo Charles J. Toovey en 1899 al banquero J. Pierpont Mogan (1837-1913). Este importante conjunto de libros y documentos, cuyo inventario fue publicado en Nueva York en 1901, en $A$ catalogue of $a$ 
lección pertenecía un lote de trece cuadros, no descritos, que fueron adquiridos por Renton en la subasta realizada en Christie's el 3 de junio de 1909 (Einberg, 1987). Un grupo de piezas del que no descartamos que puedan provenir las que nos ocupan, ya que cinco de ellas presentan en el reverso una inscripción numérica manuscrita: 13/6. Igualmente, tampoco es rechazable la idea de que estas tablas quijotescas puedan relacionarse con las seis que fueron adquiridas por W.M. Sabin and Sons en la subasta de Christie's del 29 de junio de 1956 y de las que igualmente se ignoran los episodios que reproducían (Einberg y Egerton, 1988: 228-231). 


\section{CATÁLOGO DE OBRAS EN EL MUSEO DE PONTEVEDRA}

1. Historia de Dorotea. Encuentro con Dorotea en Sierra Morena (I, cap. 28).

Óleo/tabla de roble.

40,2 x 29,8 cm.

Inscripciones: $J n .^{\circ}$ Vanderbank (ángulo inferior izquierdo).

1337/E 5555/5 100000/6 tablas (etiqueta antigua manuscrita en tinta en el reverso de la tabla).

13/6 (manuscrito en blanco en el reverso).

N. ${ }^{\circ}$ Reg. 4.097 (Figura 1).

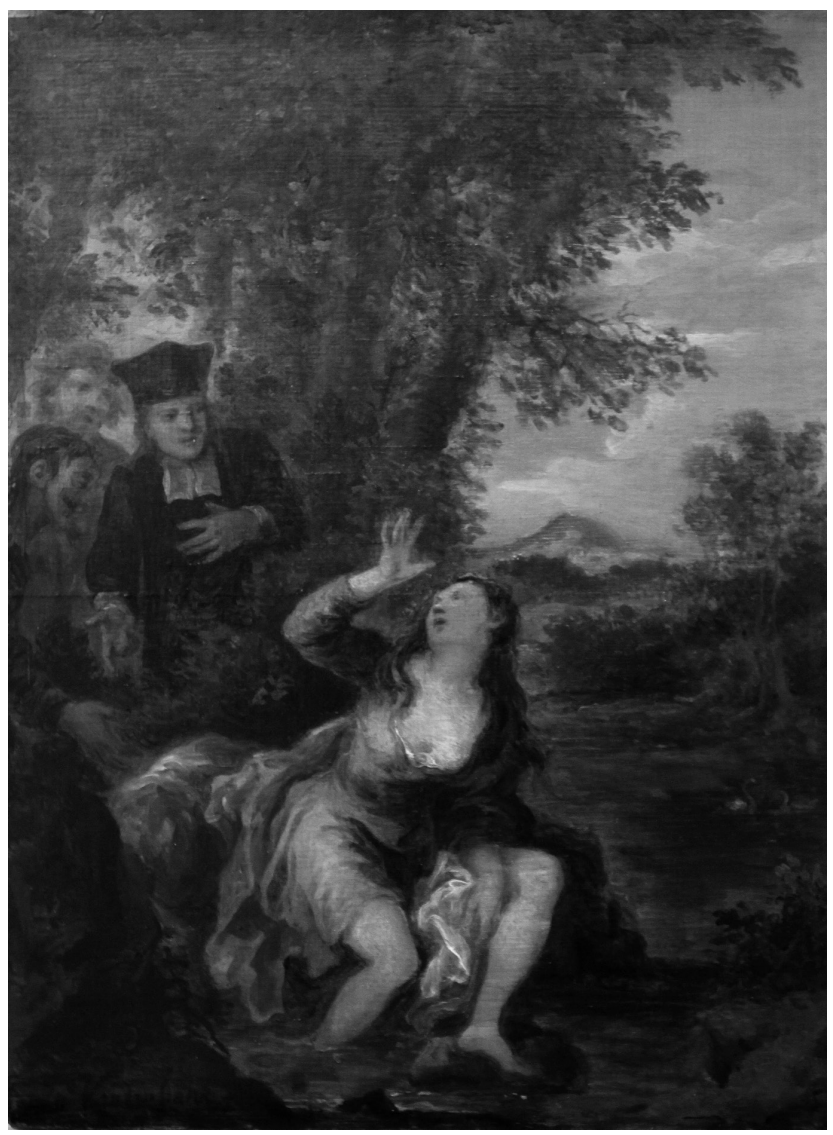

Figura 1. John Vanderbank. Historia de Dorotea. Encuentro con Dorotea en Sierra Morena (I, cap. 28). Museo de Pontevedra (N. ${ }^{\circ}$ Reg. 4.097) 


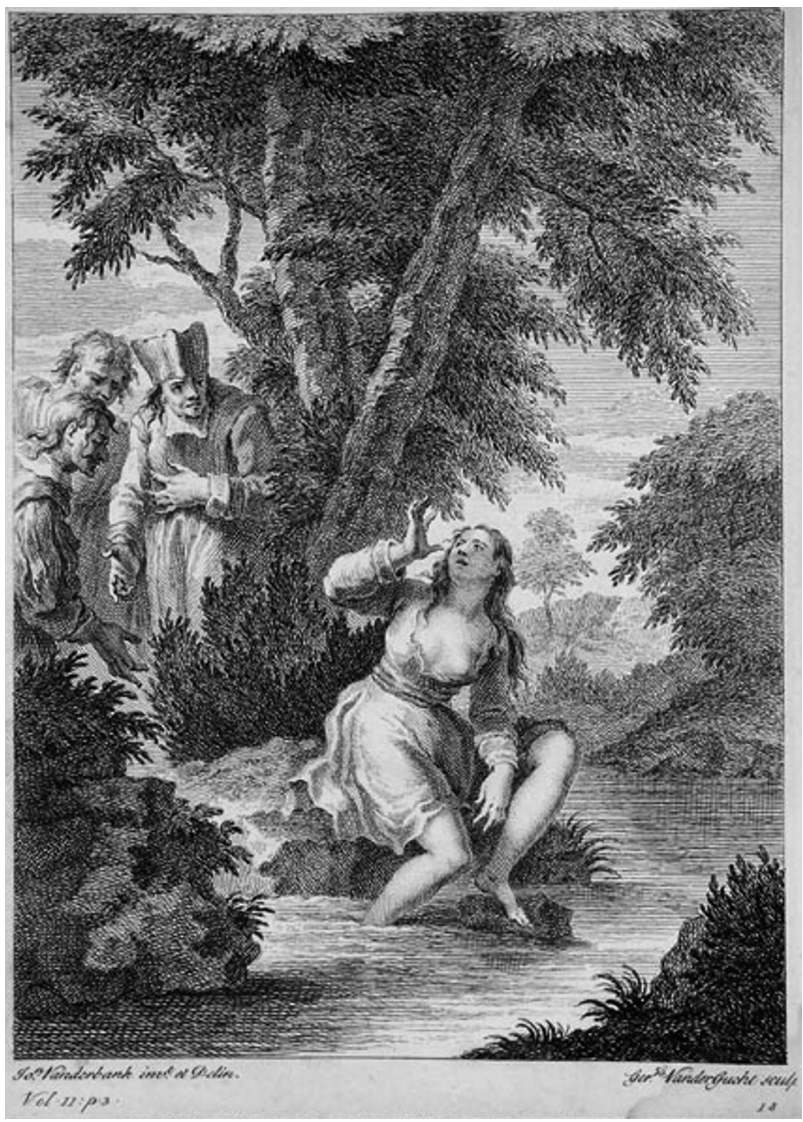

Figura 1.1. Gerard Vandergucht por dibujo de John Vanderbank. Historia de Dorotea: Encuentro con Dorotea en Sierra Morena (I, cap. 28). Estampa n. ${ }^{\circ} 18$ en Vida y hechos del ingenioso hidalgo Don Quixote de la Mancha, London, J. \& R. Tonson, 1738. Banco de imágenes del Quijote (http://www.qbi2005.com/)

En este cuadro Vanderbank repite casi literalmente la composición de la estampa n. ${ }^{\circ} 18$ de la edición londinense de 1738 que, grabada por Gerard Vandergucht ${ }^{32}$, ilustra el volumen $2 .^{\circ}$ entre las pág. 2 y 3 (Figura 1.1).

32. Gerard Vandergucht (Londres de 1696-18 de marzo de 1776). Grabador, hijo de Michael Vandergucht. Entre sus numerosos trabajos, además de en la edición del Quijote de Tonson de 1738, destacan los grabados y el frontispicio de la Complete History of the Most Remarkable Transactions at Sea (1720) de Josiah Burchett, basados en diseños de James Thornhill, y sus ilustraciones para Select Collection of Novels (2/1729) por dibujos de Joseph Highmore y John Vanderbank. Contribuyó a algunos de los libros ilustrados más ambiciosos e inusuales, como la edición de Lewis Theobald (2/1740) de Shakespeare. A partir de estas fechas, ante la creciente popularidad del estilo francés y de ilustradores como Charles Grignion y el Barón Bernard, abandonó el grabado para convertirse en distribuidor de estampas y proveedor de material para artistas en el londinense Lower Brook Street. Véase $<$ http://www.answers.com/topic/gerard-vandergucht-2> 
En la colección de The Morgan Library \& Museum de Nueva York se conserva un dibujo preparatorio, firmado y fechado por Vanderbank en 1729 , en el que la ponderada composición se muestra invertida con respecto a la estampa publicada en 1738 y también a la pintura ${ }^{33}$.

La escena, que será habitual en futuras ediciones del Quijote, reproduce el episodio en el que Dorotea es sorprendida por el cura, el barbero y Cardenio, cuando se lava los pies en un arroyo:

Todas estas razones oyeron y percibieron el cura y los que con él estaban, y por parecerles, como ello era, que allí junto las decían, se levantaron a buscar el dueño, y no hubieron andado veinte pasos, cuando detrás de un peñasco vieron sentado al pie de un fresno a un mozo vestido como labrador, al cual, por tener inclinado el rostro, a causa de que se lavaba los pies en el arroyo que por allí corría, no se le pudieron ver por entonces; y ellos llegaron con tanto silencio que dél no fueron sentidos, ni él estaba a otra cosa atento que a lavarse los pies, que eran tales, que no parecían sino dos pedazos de blanco cristal que entre las otras piedras del arroyo se habían nacido. Suspendióles la blancura y belleza de los pies, pareciéndoles que no estaban hechos a pisar terrones, ni a andar tras el arado y los bueyes, como mostraba el hábito de su dueño, y así, viendo que no habían sido sentidos, el cura, que iba delante, hizo señas a los otros dos que se agazapasen o escondiesen detrás de unos pedazos de peña que allí había, y así lo hicieron todos, mirando con atención lo que el mozo hacia; el cual traía puesto un capotillo pardo de dos haldas, muy ceñido al cuerpo con una toalla blanca. Traía ansimesmo unos calzones y polainas de paño pardo, y en la cabeza una montera parda. Tenía las polainas levantadas hasta la mitad de la pierna, que, sin duda alguna, de blanco alabastro parecía. Acabóse de lavar los hermosos pies, y luego, con un paño de tocar, que sacó de debajo de la montera, se los limpió; y al querer quitársele, alzó el rostro, y tuvieron lugar los que mirándole estaban de ver una hermosura incomparable, tal, que Cardenio dijo al cura, con voz baja:

-Esta, ya que no es Luscinda, no es persona humana, sino divina.

El mozo se quitó la montera y, sacudiendo la cabeza a una y a otra parte, se comenzaron a descoger y desparcir unos cabellos, que pudieran los del sol tenerles envidia. Con esto conocieron que el que parecía labrador era mujer, y delicada, y aun la más hermosa que hasta entonces los ojos de los dos habían visto, y aun los de Cardenio, si no hubieran mirado y conocido a Luscinda; que después afirmó que sola la belleza de Luscinda podía contender con aquélla ${ }^{34}$.

En esta obra John Vanderbank muestra algunas de las características que serán comunes al conjunto de sus composiciones quijotescas al óleo en las

33. Dorothea Discovered Washing Her Feet. Aguada y lápiz sobre papel, 27, 6 x 19,7 cm. Firmado y fechado: J. Vanderbank. Fecit. 1729 (en el margen inferior izquierdo). Dibujo procedente de la antigua colección del artista y coleccionista inglés Charles Fairfax Murray adquirido por Pierpont Morgan en 1909. N. ${ }^{\circ}$ de registro: 123430. Accesible en <http:/www.themorgan.org/drawings/ item/123430>

34. Las citas de la novela proceden de la edición digital de la Universidad de Alcalá, 1997. Accesible en $<$ http://cervantes.uah.es/quijote/httoc.htm> 
que aborda la pintura con una libertad que no se permite en sus elegantes retratos de encargo, lo que les aporta una calidad más pictórica, fresca y personal.

Con una paleta restringida y cálida, sigue fielmente la composición creada para la estampa, aunque la comprime ligeramente. Sitúa la acción sobre un paisaje en cuyo fondo destaca una montaña, alusiva a Sierra Morena, en el que es evidente que el artista sigue las huellas del paisaje clasicista de raíces italianas. En primer término, bajo una declinante luz crepuscular que aporta a la escena una delicada atmósfera dorada, sitúa la figura de Dorotea, con sus pies sumergidos en el agua de un arroyo. La mujer muestra una expresiva actitud de sorpresa y desconcierto al advertir la presencia de tres hombres semiocultos que la observan desde la parte izquierda, junto a un gran árbol cuyas ramas se extienden por encima del borde superior de la escena, potenciando el efecto de profundidad.

Frente a la concepción inicial que nos aporta el sobrio diseño preparatorio y el aguafuerte de Vandergucht, John Vanderbank refuerza en su pintura la expresividad de las figuras de los protagonistas del episodio frente a los elementos decorativos. Con este fin adelanta el encuadre para atraer a Dorotea hasta el primer plano, eliminando casi totalmente el arroyo que sí se mostraba detallado en la lámina. Del mismo modo, adelanta también ligeramente la figura del cura que, con idéntica elegancia en la disposición de sus manos que en la estampa, expresa juicio y determinación ante la visión de la joven; mientras, los otros dos hombres, Maese Nicolás y Cardenio, quedan apenas esbozados tras él.

Con pincelada sucinta, Dorotea aparece de espaldas a los hombres, pero está vestida de mujer, no disfrazada de hombre como indicaba el texto cervantino. La joven se muestra aquí con una larga cabellera suelta y con la falda remangada dejando al descubierto sus piernas. Con un gesto sorprendido, que enfatiza con la postura crispada de sus mano derecha, gira su cabeza hacia atrás dejando al descubierto parte de su voluptuoso escote en el que los reflejos de luz hacen destellar la piel nacarada de su pecho. Vanderbank no sigue literalmente la narración del texto original y para facilitar su comprensión al público evita presentar a Dorotea disfrazada de hombre y retoma la imagen creada en 1674 por Diego de Obregón, el autor de la primera edición ilustrada del Quijote impresa en España ${ }^{35}$. Lo importante aquí es la finalidad de la imagen, su capacidad para ofrecer la lectura a través de la expresión de los sentimientos de los personajes, y no tanto el mantener un perfecto víncu-

35. Diego de Obregón, uno de los más reputados dibujantes y grabadores de Madrid en la segunda mitad del XVII, fue el encargado de ilustrar esta edición popular de 1674 que, financiada por María Armenteros, tuvo una gran trascendencia en España hasta finales del s. XVIII. Obregón delimita aquí un nuevo programa iconográfico basado en el modelo holandés, que adapta al cambio de tamaño y disposición de las ilustraciones en el cuerpo del texto, ampliando la lectura humorística y de entretenimiento de la novela y modificando el programa al incluir en sus estampas algunos de los episodios más escatológicos del libro y también aquellos en los que la mujer adquiere un mayor protagonismo (Lucía Megías, 2006: 226-247). 
lo iconográfico con el texto con el que se está relacionando. Así el pintor hace más evidente la connotación erótica de la escena y para ello reinterpreta modelos clásicos protagonizados por figuras femeninas en el baño, como Betsabé, Diana o más exactamente la representación icónica del voyeurismo de Susana y los viejos. Una imagen que, como el paisaje atmosférico que enmarca la escena, resulta igualmente sugestiva en la pintura de Rubens, artista al que admiraba y que conocía a través de grabados disponibles en Inglaterra $^{36}$.

2. Aventura de los cueros de vino (I, cap. 35).

Óleo/tabla de roble.

40,5 x $29,6 \mathrm{~cm}$.

Inscripciones:

$J n .^{\circ}$ Vanderbank Ft (ángulo inferior izquierdo).

13/6 (manuscrito en blanco en el reverso).

N. ${ }^{\circ}$ Reg. 4.095 (Figura 2).

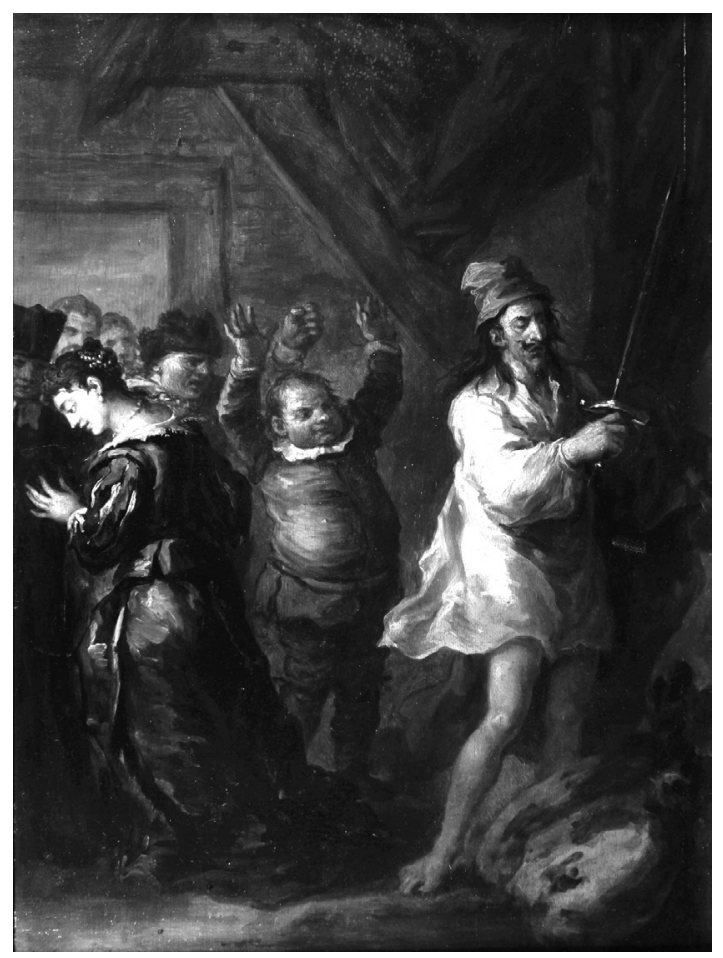

Figura 2. John Vanderbank. Aventura de los cueros de vino (I, cap. 35).

Museo de Pontevedra (N. ${ }^{\circ}$ Reg. 4.095)

36. La similitud con un estilo cercano a Rubens en la obra de Vanderbank, primer autor británico en emular el Retrato de Helena Fourment, explicaría la ya citada atribución errónea que anteriormente tuvieron este grupo de pinturas del Museo de Pontevedra a la Escuela Flamenca. 
Reproduce la composición de la estampa n. ${ }^{\circ} 21$ de la edición de 1738, de la que también se conserva un dibujo preparatorio, firmado y fechado por Vanderbank en 1729, en The Morgan Library \& Museum ${ }^{37}$. La estampa, grabada por Gerard Vandergucht, ilustra el volumen $2^{\circ}$ encuadernada entre las págs. 120 y 121 (Figura 2.1). De esta composición hay una segunda versión, también al óleo sobre tabla, que fue adquirida por Marshall Spink en Sotheby's el 15 de marzo de 1967 y que actualmente se encuentra en el York Museums Trust (York Art Gallery) ${ }^{38}$ (Figura 2.2).

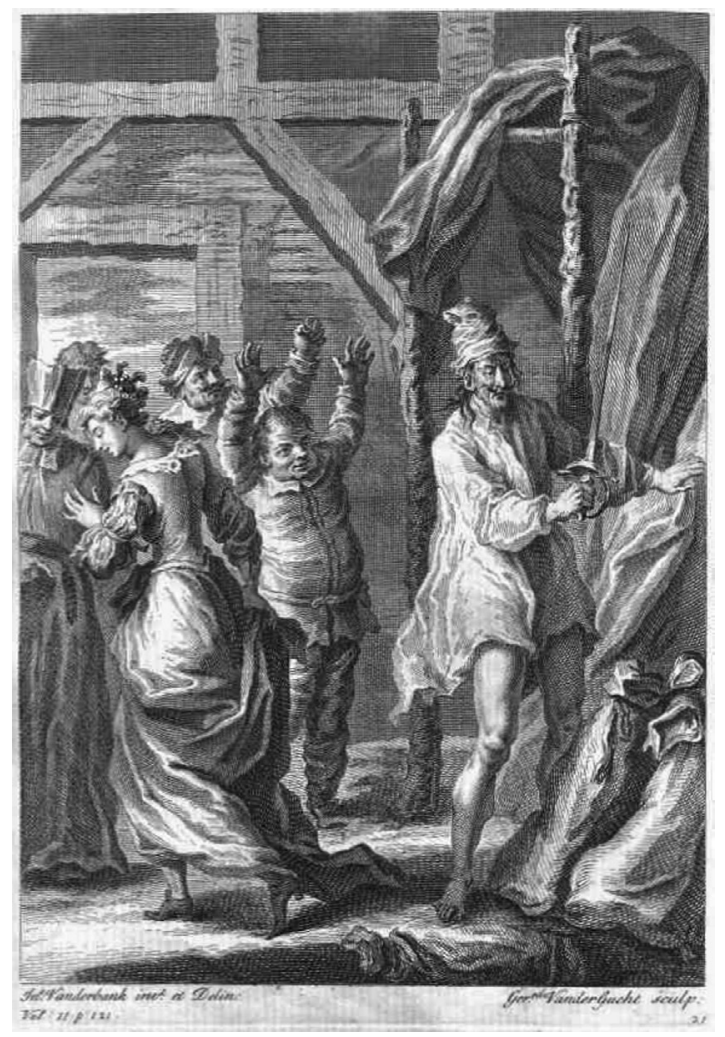

Figura 2.1. Gerard Vandergucht por dibujo de John Vanderbank. Aventura de los cueros de vino (I, cap. 35). Estampa n. ${ }^{\circ} 21$ en Vida y hechos del ingenioso hidalgo Don Quixote de la Mancha, London, J. \& R. Tonson, 1738. Banco de imágenes del

Quijote (http://www.qbi2005.com/)

37. Don Quixote Attacking the Wine-Skins in His Sleep. Aguada y lápiz sobre papel, 27, 5 x 19 cm. Firmado y fechado: J. Vanderbank. Fecit. 1729 (en el margen inferior izquierdo). Dibujo procedente de la antigua colección del artista y coleccionista inglés Charles Fairfax Murray, adquirido por Pierpont Morgan en 1909. N. ${ }^{\circ}$ de registro: 123405. Accesible en < http://www. themorgan.org/drawings/ item/123405>

38. Agradezco la colaboración del York Museums Trust (York Art Gallery), y especialmente, a Mr. Jackie Logan, Collections Management Coordinator. 


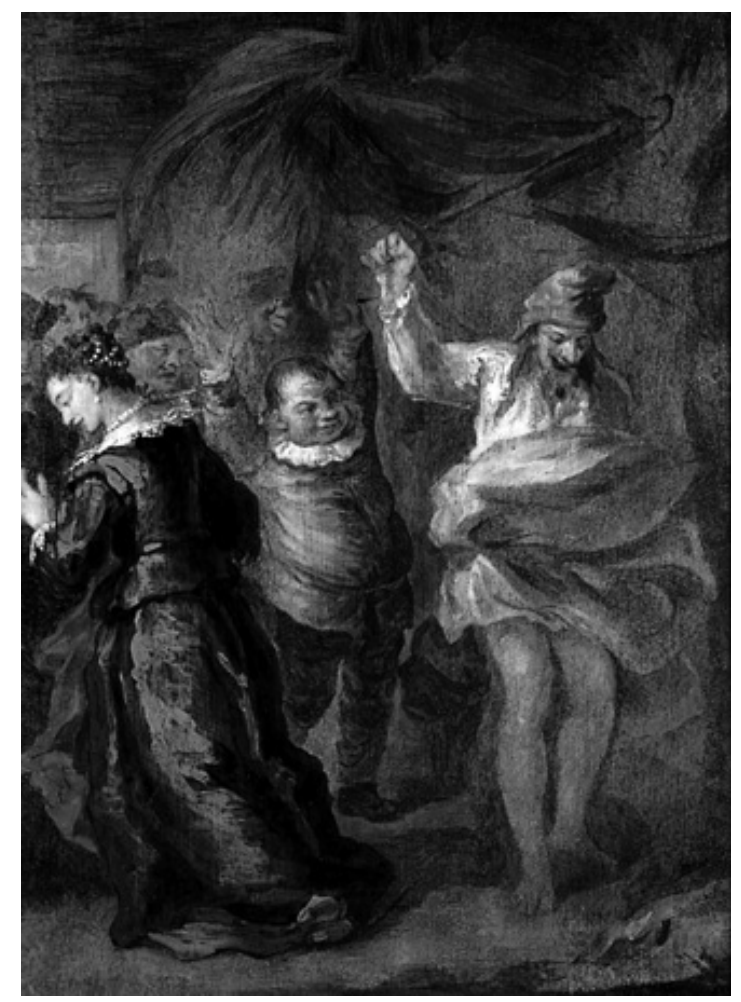

Figura 2.2. John Vanderbank. Aventura de los cueros de vino (I, cap. 35). York Museums Trust (York Art Gallery)

La obra narra uno de los más famosos episodios de la primera parte del Quijote, en el que el hidalgo manchego mantiene una batalla con los odres de vino creyendo enfrentarse a Pandafilando de la Fosca Vista, el gigante descomunal y estrábico, que tiene aterrorizada a la Princesa Micomicona:

En esto, oyeron un gran ruido en el aposento, y que don Quijote decía a voces:

-¡Tente, ladrón, malandrín, follón, que aquí te tengo, y no te ha de valer tu cimitarra!

Y parecía que daba grandes cuchilladas por las paredes. Y dijo Sancho:

-No tienen que pararse a escuchar, sino entren a despartir la pelea, o a ayudar a mi amo; aunque ya no será menester, porque, sin duda alguna, el gigante está ya muerto, y dando cuenta a Dios de su pasada y mala vida, que yo vi correr la sangre por el suelo, y la cabeza cortada y caída a un lado, que es tamaña como un gran cuero de vino.

-Que me maten -dijo a esta sazón el ventero- si don Quijote, o don diablo, no ha dado alguna cuchillada en alguno de los cueros de vino tinto que a su cabecera estaban llenos, y el vino derramado debe de ser lo que le parece sangre a este buen hombre. 
Y, con esto, entró en el aposento, y todos tras él, y hallaron a don Quijote en el más estraño traje del mundo: estaba en camisa, la cual no era tan cumplida que por delante le acabase de cubrir los muslos, y por detrás tenía seis dedos menos; las piernas eran muy largas y flacas, llenas de vello y no nada limpias; tenía en la cabeza un bonetillo colorado, grasiento, que era del ventero; en el brazo izquierdo tenía revuelta la manta de la cama, con quien tenía ojeriza Sancho, y él se sabía bien el porqué; y en la derecha, desenvainada la espada, con la cual daba cuchilladas a todas partes, diciendo palabras como si verdaderamente estuviera peleando con algún gigante.

Con técnica rápida y fluida, lo que aporta a la composición un carácter abocetado, Vanderbank reproduce fielmente en esta tabla el citado dibujo de 1729 y la estampa publicada en 1738. Esa estampa, en la que recrea e innova una escena que había aparecido por primera vez en la iconografía quijotesca en el programa creado por Jacob Harrewyn (Bruselas, 1706), el más cómico dentro del modelo iconográfico holandés es una de las que mejor ejemplifica el cambio de enfoque que, en aras de la dignificación del personaje, nos ofrece Vanderbank con sus contenidas creaciones (Lucía Megías, 2005: 120-121; 2006: 90).

En el pequeño cuadro del Museo de Pontevedra la escena se desarrolla en un interior de gran sobriedad, en el que Vanderbank prescinde incluso de los escasos detalles decorativos que se observan en la estampa y su diseño preparatorio. Elimina el dosel, que hacía referencia al lecho del que se había levantado el caballero y, en la pintura, el artista indica todavía más sumariamente el espacio. Aquí, los escuetos cortinajes que cuelgan de unas toscas vigas a la derecha, junto con la puerta abierta situada en el fondo, constituyen los únicos referentes espaciales. El artista, a través de los diferentes gestos y reacciones de los personajes, organiza la composición en dos partes contrapuestas con las que expresa la lucha entre realidad-razón e imaginación-locura, mostrando a Don Quijote en una situación de enajenación pero con respeto y consideración, sin burla ni carcajada, creando una imagen que pasará a ser un referente y que dará lugar a meditaciones e interpretaciones diversas.

A la derecha sitúa erguido y descalzo al Quijote, vestido únicamente con una corta camisa de dormir y sus largos cabellos cubiertos con un estrafalario gorro rojo, sosteniendo en alto con su mano derecha la espada con la que acaba de agujerear unos odres de vino que, desparramando su contenido, se encuentran a sus pies. La figura del hidalgo, ajeno a la realidad pero aún así sereno y digno, se sitúa de espaldas a los otros moradores de la posada que entran atropelladamente en el cuarto para comprobar el origen del tumulto que acaban de escuchar, entre ellos Sancho y el ventero que alzan los brazos en actitud de asombro. Junto a ellos se distinguen al fondo otros dos personajes y a la izquierda el cura, aquí casi oculto por la figura de Dorotea que, en primer término, gira su cuerpo emprendiendo la huida para no ver cuán corta y sutilmente estaba vestido el caballero. 
Frente a la rapidez de pincelada con la que Vanderbank define a la mayoría de los personajes del cuadro, la postura en escorzo de Dorotea, con un elegante movimiento helicoidal, está magníficamente diseñada. Representada en su papel de Princesa Micomicona ${ }^{39}$ y como tal ricamente vestida y peinada con sartas de perlas adornando su cabello, su vestido de satén azul intenso, sobre el que resaltan fuertes contrastes de luz, rompe con el entorno cálido del cuadro y destaca con energía en el austero engranaje de la obra, aportando una impresión de suntuosidad. Por otra parte, la calidad de las carnaciones rosadas y finamente pintadas de la mujer, recuerdan la técnica de Rubens que Vanderbank repite en muchos de sus bellos retratos de empaque.

Como ya citamos anteriormente existe una segunda versión, pintada también sobre tabla, de esta escena que, con unas dimensiones muy similares ${ }^{40}$, se conserva actualmente en el York Museums Trust (York Art Gallery). Esta versión muestra, sin embargo, sustanciales diferencias con la del Museo de Pontevedra. Las divergencias entre ambas no se limitan solamente a la mayor soltura de la segunda versión, que manifiesta una mayor rapidez de ejecución, o a la diferencia del color del vestido de Micomicona, aquí verde esmeralda y azul ultramar en la tabla pontevedresa, sino que afectan especialmente a la expresividad y apariencia de los personajes. Frente a la sobriedad de actitudes que presenta nuestra tabla, la de York, más colorista y decorativa, muestra una mayor gestualidad. Estamos ante una versión libre de la estampa que, de hecho, no ofrece exactamente el mismo instante del episodio narrado por Miguel de Cervantes, sino que narra el momento inmediatamente anterior. Aquí Vanderbank nos presenta a D. Quijote alterado, en pleno ataque de locura, enredado en la sábana de su cama y blandiendo agitadamente su espada contra los odres, una actitud que contrasta claramente con la serenidad presente en el cuadro del Museo de Pontevedra. Igualmente, los demás protagonistas de la escena hacen más evidentes sus emociones, como nos muestra la mueca del rostro de Sancho Panza y el mayor ímpetu de Micomicona en su huída, lo que la hacen más cercana a la entonces popular lectura cómica y de entretenimiento de la novela.

En contraste, el pequeño y cuidado cuadro del Museo de Pontevedra, uno de los más interesantes del conjunto de Vanderbank en la institución, se ajusta fielmente a los preceptos de Oldfield y, en consonancia con el gusto neoclásico del patrocinador de la serie, las expresiones de los personajes resultan, como en el dibujo de la Pierpont Morgan Library, incluso más sobrias y contenidas que en la estampa grabada por Vandergucht. Estamos ante la lectura culta de la obra y esto nos hace pensar que esta quizás pudo pertenecer a aquella primera serie de pinturas del Quijote encargada al pintor, posiblemente, por Lord Carteret; mientras la segunda versión, conservada en York,

39. Dorotea, la bella y leída joven que conoce bien las novelas de caballerías y para ayudar a la estrategia del cura de hacer regresar a casa a Don Quijote acepta hacerse pasar por una princesa que llega de un lejano reino para pedirle ayuda.

40. Mide 40,5 x 29,5 cm. 
más retórica y que por sus características parece ir destinada a una clientela menos erudita, pertenecería al segundo grupo de obras que el pintor realiza a finales de su vida como medio de rentabilizar un tema de moda.

3. Sansón Carrasco se ofrece para ser escudero de D. Quijote (II, cap. 7). Óleo/tabla de roble.

40,3 x 29,7 cm.

Inscripciones:

Vanderbank Fecit (ángulo inferior izquierdo).

13/6 (manuscrito en blanco en el reverso).

N. ${ }^{\circ}$ Reg. 4.129 (Figura 3).

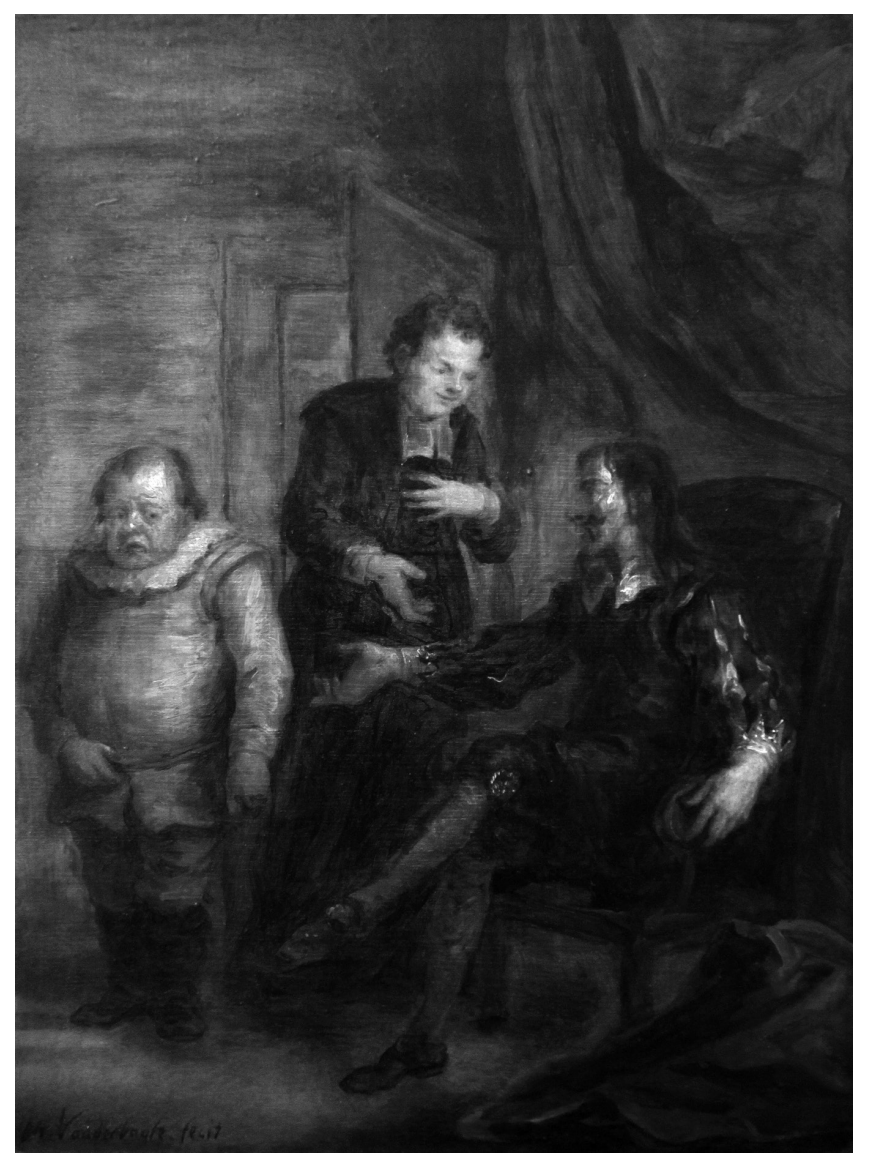

Figura 3. John Vanderbank. Sansón Carrasco se ofrece para ser escudero de D. Quijote (II, cap. 7). Museo de Pontevedra (N. ${ }^{\circ}$ Reg. 4.129) 
Reproduce, aunque invertida, como en el dibujo preparatorio de la Pierpont Morgan Library, firmado y fechado por Vanderbank en $1729^{41}$, la composición de la estampa n. ${ }^{\circ} 31$ de la edición de 1738 que, grabada también por Gerard Vandergucht, ilustra el volumen $3^{\circ}$ encuadernada entre las pág. 60 y 61 (Figura 3.1).

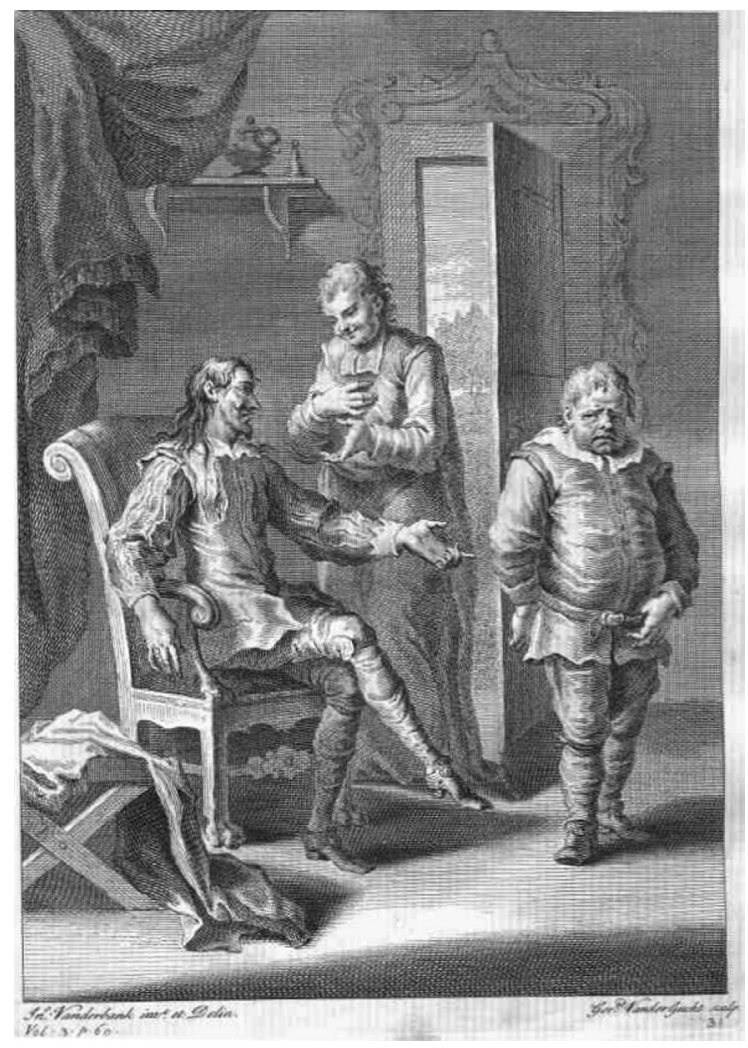

Figura 3.1. Gerard Vandergucht por dibujo de John Vanderbank. Sansón Carrasco se ofrece para ser escudero de D. Quijote (II, cap. 7). Estampa n..$^{\circ} 31$ en Vida y hechos del ingenioso hidalgo Don Quixote de la Mancha, London, J. \& R. Tonson, 1738. Banco de imágenes del Quijote (http://www.qbi2005.com/)

El cuadro narra el episodio incluido en el capítulo 7 de la segunda parte del libro, publicada por Miguel de Cervantes en 1615, en el que el bachiller Sansón Carrasco se ofrece para ser escudero de Don Quijote:

41. Don Quixote Reproaching Sancho for His Ingratitude. Aguada y lápiz sobre papel, 27, 9 x 19,8 cm. Firmado y fechado: J. Vanderbank. Fecit. 1729 (en el margen inferior izquierdo). Dibujo adquirido por Pierpont Morgan en 1909. N. ${ }^{\circ}$ de registro: 123421. Accesible en $<$ http://www.themorgan. org/drawings/item/123421> 
...¡Ea, señor don Quijote mío, hermoso y bravo, antes hoy que mañana se ponga vuestra merced y su grandeza en camino; y si alguna cosa faltare para ponerle en ejecución, aquí estoy yo para suplirla con mi persona y hacienda; y si fuere necesidad servir a tu magnificencia de escudero, lo tendré a felicísima ventura!

A esta sazón, dijo don Quijote, volviéndose a Sancho:

- ¿No te dije yo, Sancho, que me habían de sobrar escuderos? Mira quién se ofrece a serlo, sino el inaudito bachiller Sansón Carrasco, perpetuo trastulo y regocijador de los patios de las escuelas salmanticenses, sano de su persona, ágil de sus miembros, callado, sufridor así del calor como del frío, así de la hambre como de la sed, con todas aquellas partes que se requieren para ser escudero de un caballero andante.

La escena se sitúa en un interior de total sobriedad en el que nuevamente la tridimensionalidad del espacio se expresa de forma muy concisa. La estampa y el dibujo muestran escasos elementos decorativos, una moldurada puerta entreabierta, una repisa, cortinajes y una banqueta sobre la que reposa un paño que en la pintura han sido totalmente eliminados. Aquí, el fondo queda totalmente abocetado, solo enmarcado por una cortina que pende del lado derecho y un paño de terciopelo rojo que destaca en el ángulo inferior del mismo lado, para centrarse y destacar el intenso diálogo que, a través de gestos y miradas, se establece entre los tres protagonistas que, para ello, se adelantan hasta el primer plano.

Con una pincelada muy suelta y una entonación de tonos pardos, la escena muestra una composición piramidal. A la derecha, sentado con las piernas cruzadas en un sencillo sillón, mucho más simple que el de la estampa, se encuentra Don Quijote. Se le representa, de perfil a la izquierda, como un maduro y elegante caballero vestido a la manera de los cortesanos ingleses, con un traje negro formado por casaca con cuello blanco, calzones ajustados, medias a la rodilla y zapatos de lazo. El hidalgo muestra una actitud distendida mientras conversa con un joven clérigo que, situado de pie a su derecha, centra la escena. Se trata del bachiller Sansón Carrasco, personaje que tendrá un rol trascendental en el desarrollo de la novela de Cervantes, al que Vanderbank retrata vestido como clérigo de órdenes menores y siguiendo la descripción que del mismo hace el libro: Era el bachiller, aunque se llamaba Sansón, no muy grande de cuerpo, aunque muy gran socarrón, de color macilenta, pero de muy buen entendimiento; tendría hasta veinte y cuatro años, carir[r]edon-do, de nariz chata y de boca grande, señales todas de ser de condición maliciosa y amigo de donaires y de burlas... (II, cap. 3). Sansón se muestra aquí en actitud reverente, con una mano en su pecho y la otra extendida hacia Don Quijote, mostrando el instante en que le solicita convertirse en su escudero.

En el lado izquierdo, destacado por el efecto de luz que le incide directamente y por la posición de la mano derecha del caballero extendida hacia él, se sitúa Sancho Panza. El rechoncho escudero, dignamente vestido en tono pardo, con pantalón y casaca ceñida a la cintura y golilla al cuello, nos trans- 
mite un sentimiento de profunda congoja a través de la fuerte expresividad que el pintor infunde a su rostro encendido que parece a punto de estallar en llanto. El motivo de tanta desazón viene determinado porque poco antes, durante los preparativos de su salida hacia Zaragoza, Sancho, en quien aún predomina lo material, le pide a su amo que le asigne un salario, pretensión a la que Don Quijote le había contestado: Y, finalmente, quiero decir, y os digo, que si no queréis venir a merced conmigo y correr la suerte que yo corriere, que Dios quede con vos y os haga un santo; que a mí no me faltarán escuderos más obedientes, más solícitos, y no tan empachados ni tan habladores como vos.

4. El encantamiento de Dulcinea. Don Quijote y Sancho se postran ante Dulcinea encantada (II, cap. 10).

Óleo/tabla de roble.

40,5 x 29,4 cm.

Inscripciones:

Vanderbank Fecit (ángulo inferior derecho).

13/6 (manuscrito en blanco en el reverso)

N. ${ }^{\circ}$ Reg. 4.098 (Figura 4)

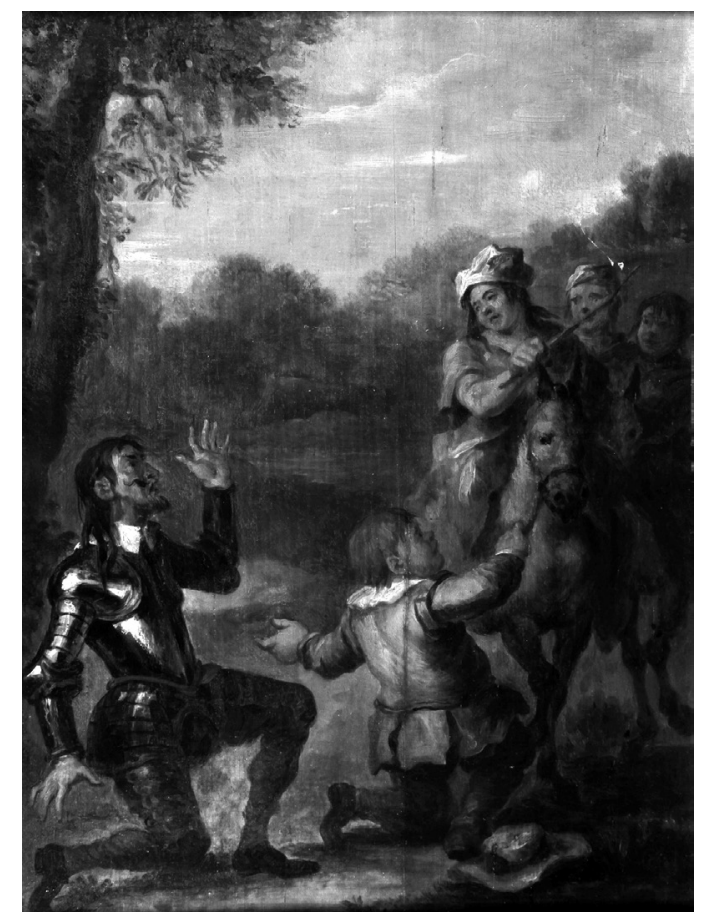

Figura 4. John Vanderbank. El encantamiento de Dulcinea. Don Quijote y Sancho se postran ante Dulcinea encantada (II, cap. 10). Museo de Pontevedra (N. ${ }^{\circ}$ Reg. 4.098) 
Reproduce, también invertida, la composición de la estampa n. 32 de la edición de 1738 que, grabada por Gerard Vandergucht, ilustra el volumen $3^{\circ}$ encuadernada entre las pág. 84 y 85 (Figura 4.1).

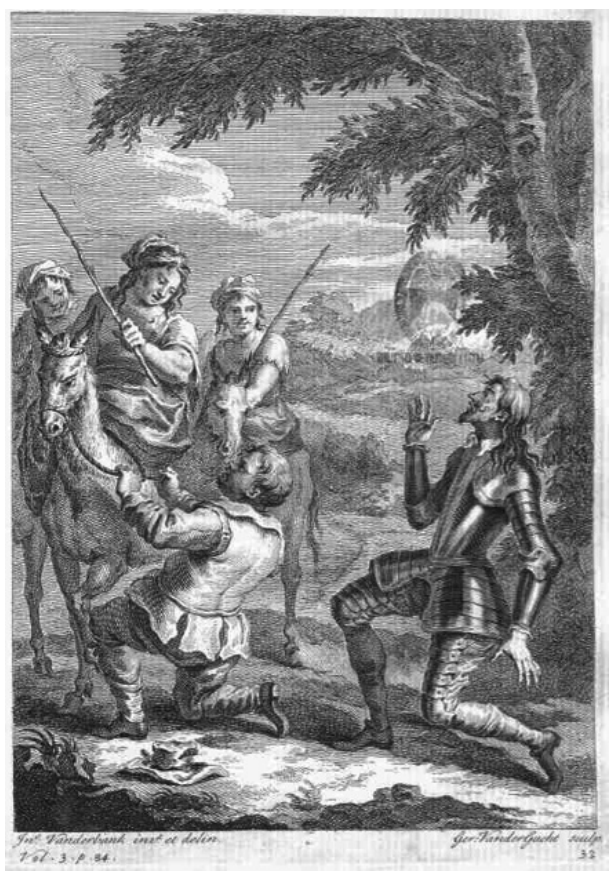

Figura 4.1. Gerard Vandergucht por dibujo de John Vanderbank. El encantamiento de Dulcinea. Don Quijote y Sancho se postran ante Dulcinea encantada

(II, cap. 10). Estampa n. ${ }^{\circ} 32$ en Vida y hechos del ingenioso hidalgo Don Quixote de la Mancha, London, J. \& R. Tonson, 1738. Banco de imágenes del Quijote (http://www.qbi2005.com/)

En el cuadro Vanderbank muestra la misma orientación que en su dibujo preparatorio que, como los citados anteriormente, fechado en 1729, se conserva también en la Pierpont Morgan Library ${ }^{42}$. Retomado el modelo iconográfico creado por el grabador y editor Jacob Savery (1617-1666) para la edición holandesa publicada en Dordrecht en 1657 (Lucía Megías, 2005: 33-57), el pintor inglés narra aquí el episodio del falso encantamiento de Dulcinea incluido en el capítulo 10 de la segunda parte de la novela. En él se refiere como, para evitar un problema con su demente amo, el avispado San-

42. Sancho Makes Don Quixote Believe that Three Country Girls are Dulcinea and Her Attendants. Aguada y lápiz sobre papel, 27,8 x 20,2 cm. Firmado y fechado: J. Vanderbank. Fecit. 1729 (en el margen inferior izquierdo). Dibujo adquirido por Pierpont Morgan en 1909. N. ${ }^{\circ}$ de registro: 123442. Accesible en <http:/www.themorgan.org/drawings/item/123442> 
cho Panza inventa que tres mozas montadas en sus burros son en realidad bellas damas. Don Quijote al verlas confiesa al escudero que él no ve más que a tres simples aldeanas, pero Sancho continúa con su engaño y se arrodilla ante una de ellas, Aldonza Lorenzo, asegurando que esta es en realidad Dulcinea del Toboso, convertida en labradora por un mal encantamiento:

Y, diciendo esto, se adelantó a recebir a las tres aldeanas; y, apeándose del rucio, tuvo del cabestro al jumento de una de las tres labradoras, $\mathrm{y}$, hincando ambas rodillas en el suelo, dijo:

-Reina y princesa y duquesa de la hermosura, vuestra altivez y grandeza sea servida de recebir en su gracia y buen talente al cautivo caballero vuestro, que allí está hecho piedra mármol, todo turbado y sin pulsos de verse ante vuestra magnífica presencia. Yo soy Sancho Panza, su escudero, y él es el asendereado caballero don Quijote de la Mancha, llamado por otro nombre el Caballero de la Triste Figura.

A esta sazón, ya se había puesto don Quijote de hinojos junto a Sancho, y miraba con ojos desencajados y vista turbada a la que Sancho llamaba reina y señora, [y], como no descubría en ella sino una moza aldeana, y no de muy buen rostro, porque era carirredonda y chata, estaba suspenso y admirado, sin osar desplegar los labios. Las labradoras estaban asimismo atónitas, viendo aquellos dos hombres tan diferentes hincados de rodillas, que no dejaban pasar adelante a su compañera...

Con una paleta restringida y cálida, Vanderbank sigue aquí fielmente la composición diagonal creada en el dibujo, que aparece invertida en la estampa, y la comprime, situando la acción sobre el característico paisaje atmosférico, de raíces clasicistas y luz crepuscular, que repite habitualmente en su pintura. A la izquierda, con su distintiva factura abocetada, sitúa montadas sobre pollinos las figuras de las tres campesinas, en las que hace ostensible la vulgaridad física con la que las describe el texto de Cervantes. Encabeza el grupo Aldonza Lorenzo, la gruesa y poco agraciada moza que, más definida en la pintura que sus compañeras, apenas esbozadas en segundo plano, eleva un palo que lleva en su mano derecha reaccionando, aunque con una gestualidad aún más contenida que en la estampa, al sobresalto y el enfado que le producen las actitudes de Sancho y Don Quijote.

A la derecha de la moza, en el centro de la composición, se sitúa Sancho Panza, arrodillado y sosteniendo, reverencialmente, las riendas de la montura de la falsa Dulcinea. En la figura y disposición del asno se percibe la habilidad de Vanderbank para presentar la anatomía y el movimiento de los équidos, presente también en otras escenas quijotescas en las que representa a Rocinante, una destreza que había perfeccionado y que se hace evidente en sus retratos ecuestres y especialmente en los dibujos que realizó para las ilustraciones de Twenty-five Actions of the Manage Horse, editado en $1729^{43}$.

43. Twenty five actions of the manage horse: engraved by Josephus Sympson, from original drawings of Mr. John Vanderbanck: To which are added, two of the English hunter..., London, printed for and sold by J. Sympson and Andrew Johnston Engraver, 1729. 
En el extremo izquierdo de la diagonal se sitúa D. Quijote, con su rodilla derecha en tierra, mostrando con sus expresivas manos un sobrio gesto de desconcierto al no poder reconocer en la burda campesina a Dulcinea, dama a la que desea pedir su bendición antes de emprender nuevas aventuras. El hidalgo lleva la cabeza sin cubrir, con el cabello suelto y largo, y vestido con una rica armadura, lo que le aproxima más a una dignidad real que a la representación de un humilde hidalgo manchego, no en vano, Vanderbank toma como modelo el retrato ecuestre de Carlos I (National Galley, Londres) de su admirado Van Dyck. Esta transformación dignificada del Quijote, asimilándolo a la figura del rey Carlos I, «el caballero de los caballeros» destituido y decapitado en Londres en 1649, está muy en consonancia con los criterios whigs de Carteret y Oldfield que, como hemos visto, guiaron el desarrollo teórico de las ilustraciones del Quijote, en tanto en cuanto rechazaban a los Estuardo y, desde la Revolución Gloriosa de 1688, se enfrentaban a los constantes levantamientos jacobitas. Una representación que sería evidente y fácilmente reconocible para el público inglés de comienzos del siglo XVIII que convivía con esos asuntos políticos y culturales y, por lo tanto, no eran indiferentes para el lector culto del Quijote, que tanto podía relacionar los desvaríos del héroe de Cervantes con el fanatismo religioso como con la búsqueda insensata de la gloria política (Paulson, 1998: 47-50; Lenaghan, 2005: 63-87).

\section{Broma en casa de los Duques: Sancho sale corriendo del lugar del} lavatorio de la barba (II, cap. 32).

Óleo/tabla de roble.

40,7 x 29,4 cm.

Inscripciones:

Etiqueta antigua: 1337/E 5555/S 100000/6 tablas (manuscrita en tinta en el reverso de la tabla).

13/6 (manuscrito en blanco en el reverso).

N. ${ }^{\circ}$ Reg. 4.096 (Figura 5).

Vanderbank diseñó para ilustrar el capítulo 32 de la segunda parte del Quijote, titulado Bromas en casa de los Duques, tres estampas. De la primera de ellas, la n. ${ }^{\circ} 41$ de la serie, que narra el momento en el que Don Quijote ordena a Sancho agradecer al Duque el cargo de gobernador de la Ínsula Barataria, no conocemos, hasta la fecha, ninguna versión al óleo. De la segunda de las ilustraciones, n. ${ }^{\circ} 42$, que muestra el instante en el que Cuatro doncellas lavan la barba a Don Quijote, se conoce la existencia de dos versiones al óleo, una sobre lienzo que fue adquirida por Marshall Spink en Sotheby's el 15 de marzo de 1967, y la pequeña tabla que actualmente se conserva en Marble Hill House, Twickenham, Richmond Middlesex ${ }^{44}$, de similares características a esta que posee el Museo de Pontevedra, réplica de

44. Véanse las notas 17 y 20. 


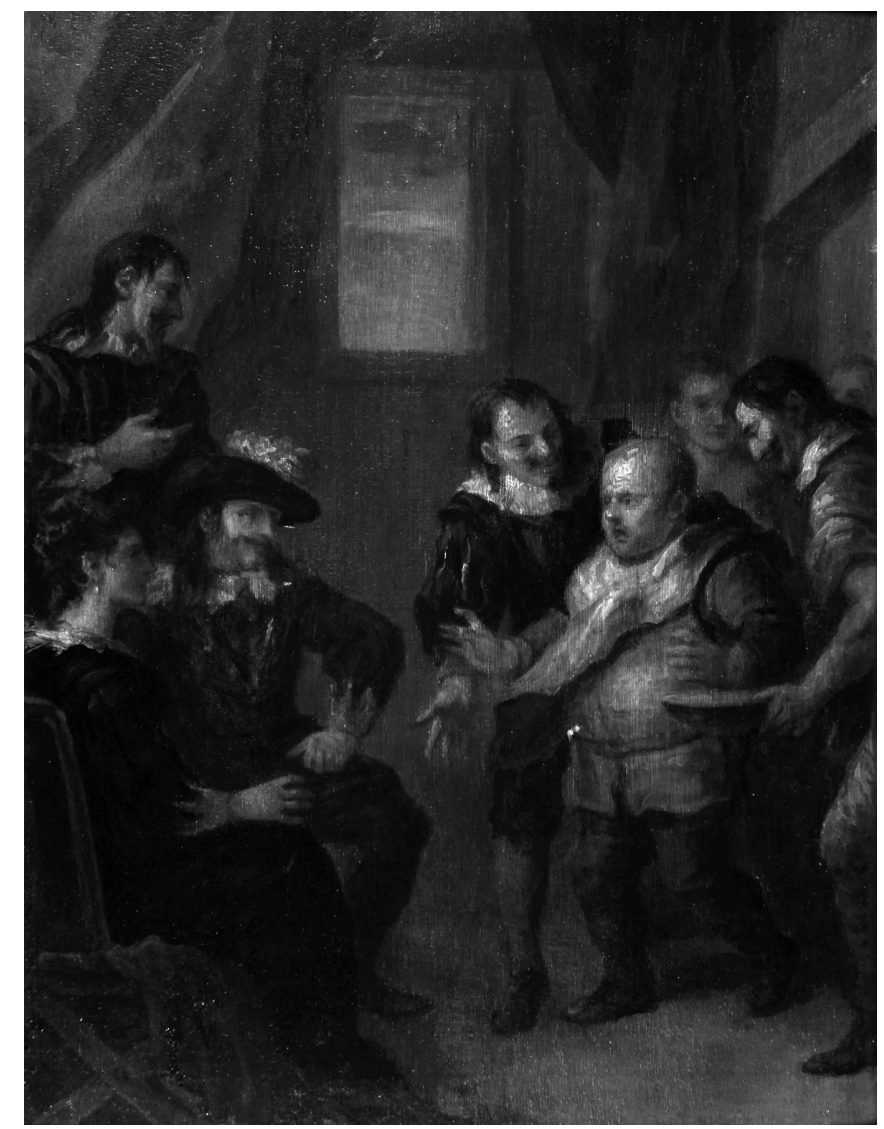

Figura 5. John Vanderbank. Broma en casa de los Duques: Sancho sale corriendo del lugar del lavatorio de la barba (II, cap. 32). Museo de Pontevedra (N. ${ }^{\circ}$ Reg. 4.096)

la tercera de las ilustraciones, que se corresponde con la n..$^{\circ} 43$ de la serie que, grabada por Claude du $\operatorname{Bosc}^{45}$ y encuadernada entre las pág. 308 y 309, ilustra como las anteriores el volumen $3^{\circ}$ de la edición (Figura 5.1). Una estampa de la que también, la Pierpont Morgan Library conserva el diseño preparatorio, en esta ocasión firmado y datado por Vanderbank el 28 de agosto de $1729^{46}$.

45. Destacado grabador nacido en Francia y establecido en Inglaterra desde 1712. Para la edición londinense del Quijote de 1738 grabó, además de esta estampa n. ${ }^{\circ} 43$, la n. 39 que ilustra el capítulo 47 y la n. ${ }^{\circ} 49$, perteneciente al capítulo 48 , todas ellas en la segunda parte de la novela.

46. Sancho Runs into the Duchess's Room to Escape from the Kitchen Boys. Aguada y lápiz sobre papel, 27,9 x 19,8 cm. Firmado y fechado: Jno Vanderbank. Fecit. August 28. 1729 (en el margen inferior izquierdo). Dibujo adquirido por Pierpont Morgan en 1909. N. ${ }^{\circ}$ de registro: 123446. Accesible en $<$ http://www.themorgan.org/drawings/item/123446> 


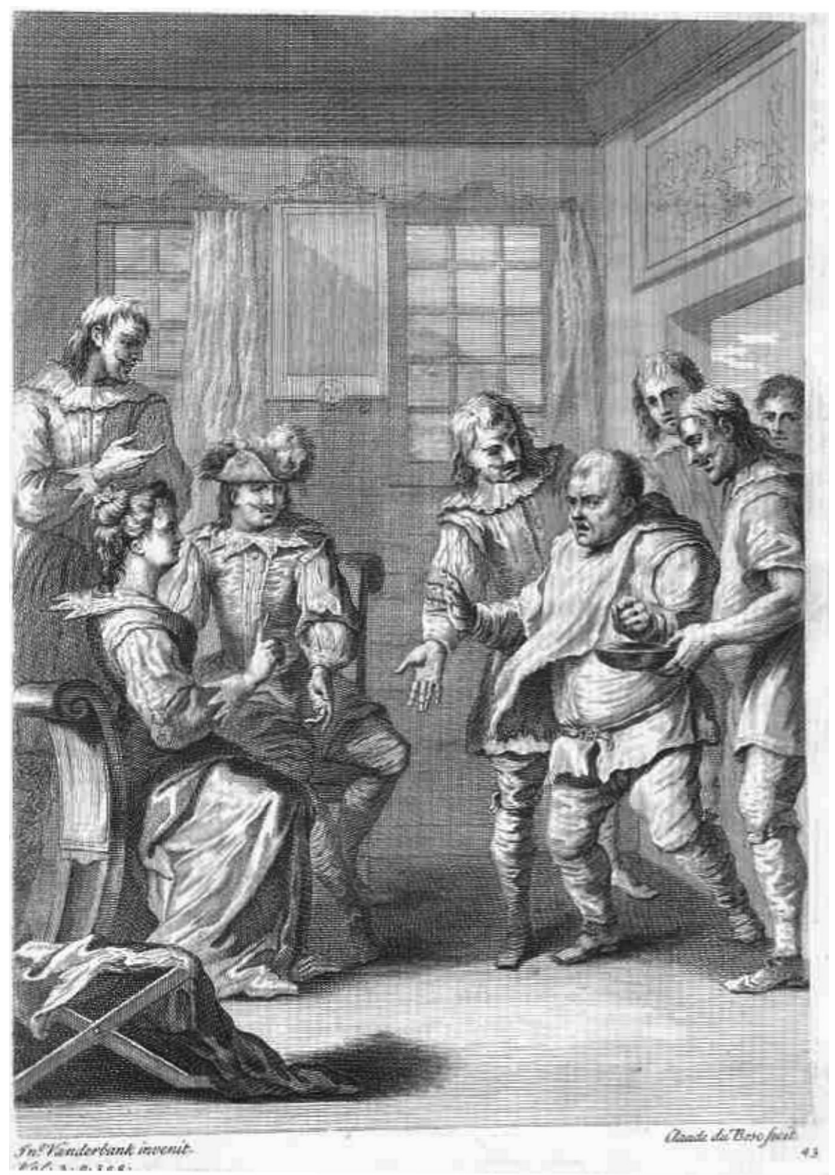

Figura 5.1. Claude du Bosc por dibujo de John Vanderbank. Broma en casa de los Duques: Sancho sale corriendo del lugar del lavatorio de la barba (II, cap. 32). Estampa n. ${ }^{\circ} 43$ en Vida y hechos del ingenioso hidalgo Don Quixote de la Mancha, London, J. \& R. Tonson, 1738. Banco de imágenes del Quijote (http://www.qbi2005.com/)

La obra narra el momento en el que Sancho, interrumpiendo la conversación entre Don Quijote y los nobles, entra en el salón de la casa de los Duques huyendo de varios criados que quieren lavar su barba con agua sucia:

A este punto llegaban de su coloquio el duque, la duquesa y don Quijote, cuando oyeron muchas voces y gran rumor de gente en el palacio; y a deshora entró Sancho en la sala, todo asustado, con un cernadero por babador, y tras él muchos mozos, o, por mejor decir, pícaros de cocina y otra gente menuda, y uno venía con un artesoncillo de agua, que en la color y poca limpieza mostraba ser de fregar; seguíale y perseguíale el de 
la artesa, y procuraba con toda solicitud ponérsela y encajársela debajo de las barbas, y otro pícaro mostraba querérselas lavar.

-¿Qué es esto, hermanos? - preguntó la duquesa-. ¿Qué es esto? ¿Qué queréis a ese buen hombre? ¿Cómo y no consideráis que está electo gobernador?

A lo que respondió el pícaro barbero:

-No quiere este señor dejarse lavar, como es usanza, y como se la lavó el duque mi señor y el señor su amo.

-Sí quiero -respondió Sancho con mucha cólera-, pero querría que fuese con toallas más limpias, con lejía mas clara y con manos no tan sucias; que no hay tanta diferencia de mí a mi amo, que a él le laven con agua de ángeles y a mí con lejía de diablos. Las usanzas de las tierras y de los palacios de los príncipes tanto son buenas cuanto no dan pesadumbre, pero la costumbre del lavatorio que aquí se usa peor es que de diciplinantes. Yo estoy limpio de barbas y no tengo necesidad de semejantes refrigerios; y el que se llegare a lavarme ni a tocarme a un pelo de la cabeza, digo, de mi barba, hablando con el debido acatamiento, le daré tal puñada que le deje el puño engastado en los cascos; que estas tales ceremonias y jabonaduras más parecen burlas que gasajos de huéspedes.

Vanderbank reproduce fielmente en este óleo el diseño establecido para la estampa en el que, a su vez, reinterpreta de nuevo un modelo iconográfico de Jacob Savery (1617-1666), aparecido por primera vez en la edición del Quijote publicada en Dordrecht en 1657 (Lucía Megías, 2005: 33-57). Aquí sitúa la escena en el austero interior del salón de la casa de los Duques y como en las tablas analizadas anteriormente las referencias al espacio doméstico son mínimas. Simplifica al máximo los detalles decorativos, ya escuetos en el dibujo y la estampa, que aquí se reducen a una ventana abierta al exterior y unos sobrios cortinajes que le sirven para acentuar el efecto de profundidad, para centrarse en la expresividad de los personajes.

Con su característico estilo amplio y rápido y su entonación parda, Vanderbank ajusta la composición al diálogo entre dos grupos de personajes que se sitúan enfrentados. A la derecha Sancho Panza que irrumpe rodeado de un grupo de criados de los que intenta huir. Los gestos del escudero, sobre el que hace incidir un potente foco de luz, denotan la contrariedad que le provoca el intento de lavarle con agua sucia haciendo patente su protesta a los nobles. A la izquierda se sitúan sentados los Duques y en segundo término, de pie, Don Quijote, de nuevo vestido con el traje oscuro de cortesano inglés. Este segundo grupo muestra, frente a la estampa que le sirve de base, una inferior calidad y, además de un menor detallismo en la descripción de los ricos ropajes de los nobles, es menos evidente la actitud de conversación entre los personajes, a lo que contribuyen las variaciones introducidas en la disposición de las manos del Duque y la Duquesa, lo que les hace más estáticos y menos expresivos. 
6. Sancho Panza tiene que defender su ínsula (II, cap. 53).

Óleo/tabla de roble.

40,7 x $29,8 \mathrm{~cm}$.

Inscripciones:

Jn. ${ }^{\circ}$ Vanderbank Fecit (ángulo inferior izquierdo).

N. ${ }^{\circ}$ Reg. 4.094 (Figura 6).

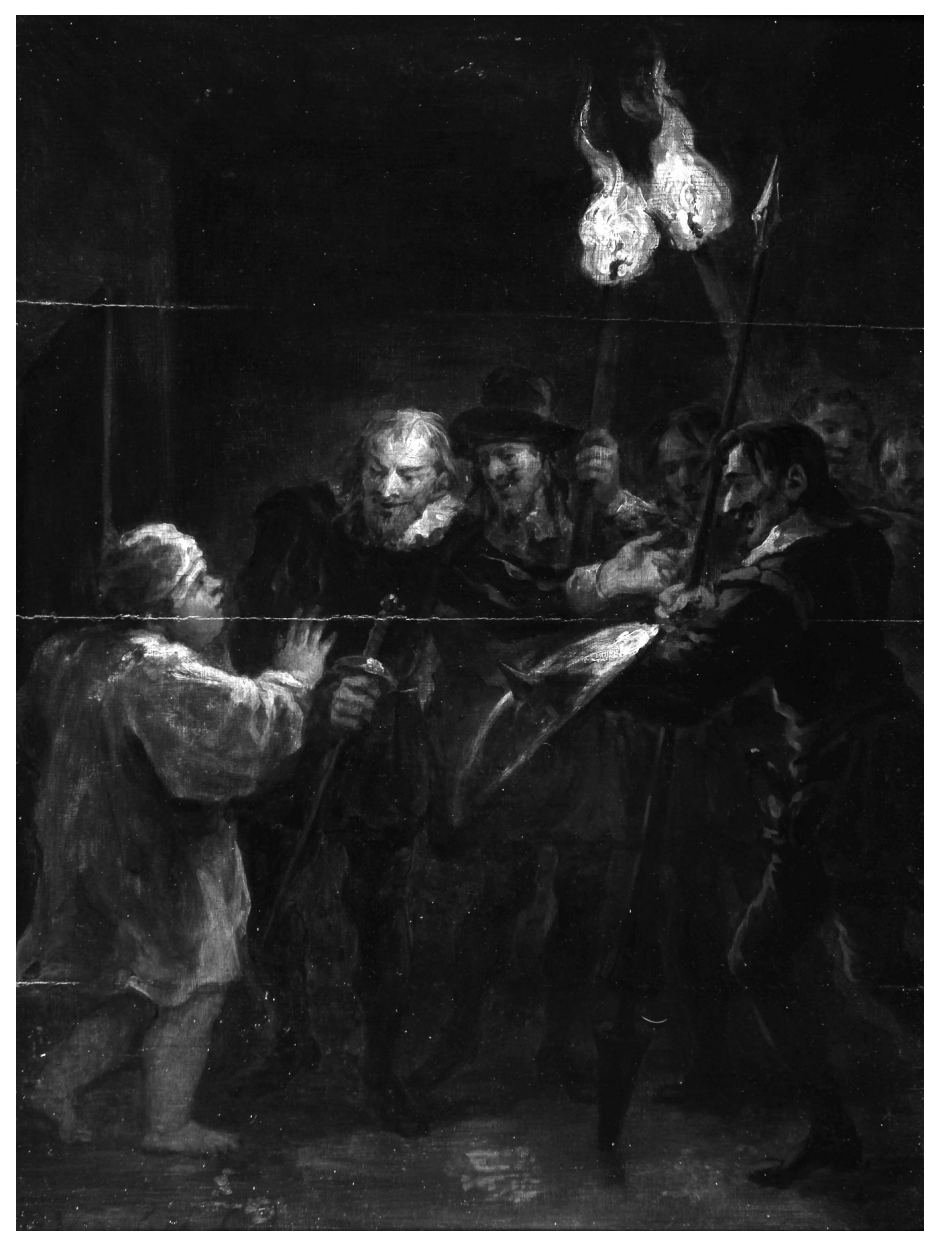

Figura 6. John Vanderbank Sancho Panza tiene que defender su insula (II, cap. 53). Museo de Pontevedra (N. ${ }^{\circ}$ Reg. 4.094)

Copia invertida del original reproducido en la estampa $n .^{\circ} 51$, grabado por Gerard Vandergucht, que ilustra el volumen $4^{\circ}$ de la edición de 1738 y está encuadernado entre las pág. 182 y 183 (Figura 6.1), siguiendo la misma dis- 
posición que presenta el dibujo preparatorio fechado por el inglés en 1729 y también conservado en la Pierpont Morgan Library ${ }^{47}$.

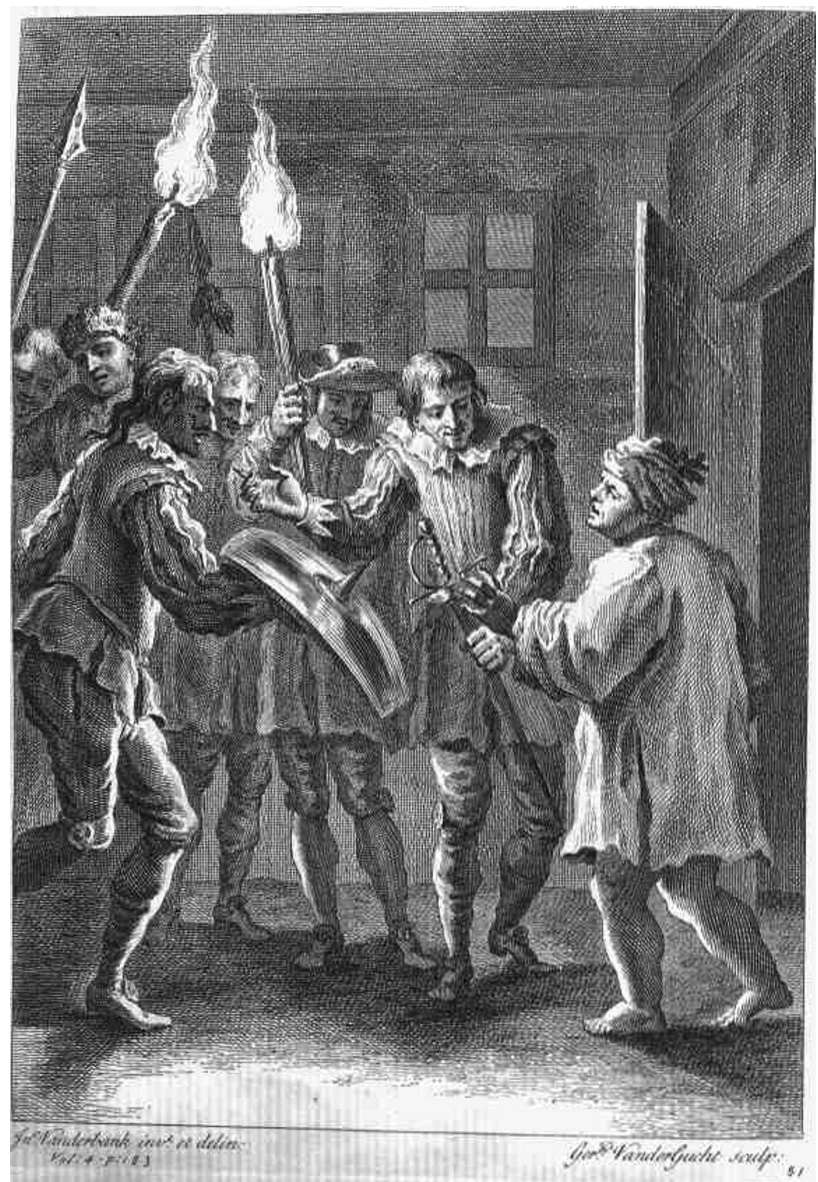

Figura 6.1. Gerard Vandergucht por dibujo de John Vanderbank. Sancho Panza tiene que defender su ínsula (II, cap. 53). Estampa n. ${ }^{\circ} 51$ en Vida y hechos del ingenioso hidalgo Don Quixote de la Mancha, London, J. \& R. Tonson, 1738

Banco de imágenes del Quijote (http://www.qbi2005.com/)

La obra narra el momento en el que Sancho Panza intenta liderar la defensa de la ínsula de Barataria de la que había sido nombrado Gobernador:

47. Sancho Alarmed in the Night on Pretence of His Island Being Invaded. Aguada y lápiz sobre papel, 27,4 x 19,7 cm. Firmado y fechado: Jon Vanderbank. Fecit. 1729 (en el margen inferior izquierdo). Dibujo adquirido por Pierpont Morgan en 1909. N. ${ }^{\circ}$ de registro: 123447. Accesible en $<$ http:// www.themorgan.org/drawings/item/123437> 
El cual, estando la séptima noche de los días de su gobierno en su cama, no harto de pan ni de vino, sino de juzgar y dar pareceres y de hacer estatutos y pragmáticas, cuando el sueño, a despecho y pesar de la hambre, le comenzaba a cerrar los párpados, oyó tan gran ruido de campanas y de voces, que no parecía sino que toda la ínsula se hundía. Sentóse en la cama, y estuvo atento y escuchando, por ver si daba en la cuenta de lo que podía ser la causa de tan grande alboroto; pero no sólo no lo supo, pero, añadiéndose al ruido de voces y campanas el de infinitas trompetas y atambores, quedó más confuso y lleno de temor y espanto; y, levantándose en pie, se puso unas chinelas, por la humedad del suelo, y, sin ponerse sobrer[r]opa de levantar, ni cosa que se pareciese, salió a la puerta de su aposento, a tiempo cuando vio venir por unos corredores más de veinte personas con hachas encendidas en las manos y con las espadas desenvainadas, gritando todos a grandes voces:

-¡Arma, arma, señor gobernador, arma!; que han entrado infinitos enemigos en la ínsula, y somos perdidos si vuestra industria y valor no nos socorre.

Vanderbank, como en las dos escenas descritas anteriormente, se basa para la creación de esta estampa en la imagen de Jacob Savery para la edición holandesa de 1657 pero, como en las anteriores, el resultado final resulta muy diferente. El artista inglés, de nuevo con una composición muy simple, se sitúa en el inicio del episodio, cuando un sorprendido Sancho sale de su aposento para conocer el origen del tumulto pero, en el personaje, ya nada queda de la imagen grotesca que aparecía en la primera iconografía del Quijote (Lucía Megías, 2005: 112-113).

La tabla, que presenta engatillado antiguo en el reverso, muestra a la izquierda la pequeña y gruesa figura de Sancho Panza vestido con su camisa de dormir y un gorro blanco en la cabeza. A la derecha se sitúa un numeroso grupo de soldados, dos de los cuales le ofrecen a Sancho un escudo y una espada, incitándole a la defensa de Barataria, estableciéndose un diálogo de gestos y miradas entre ellos.

A pesar de la intensidad del momento narrado, el cuadro no expresa un excesivo movimiento. La composición está más comprimida que en la estampa, con los personajes más adelantados, para fijar nuestra atención en sus contenidas y sobrias expresiones, aquí potenciadas por los fuertes contrastes de luz y de sombra. La iluminación, que proviene de dos antorchas que portan a la derecha los soldados, destella con luz rojiza sobre las figuras definidas con trazo rápido y espontáneo. El resto del cuadro queda en la oscuridad y, nuevamente, el espacio arquitectónico, apenas esbozado, aparece semioculto. Los efectos de claroscuro, con una luz casi mística, que realza el carácter dramático del episodio, nos ponen en relación con la pintura holandesa y francesa del s. XVII. De esta composición hay una segunda versión, también sobre tabla de pequeño formato, que fue adquirida por Marshall Spink en Sotheby's el 15 de marzo de 1967 y que actualmente se encuentra en paradero desconocido (Einberg y Egerton, 1988: 228-231). 


\section{CONCLUSIÓN}

Estas seis tablas del Museo de Pontevedra, que contribuyen a ampliar el ya importante catálogo de John Vanderbank, artista paradigmático y pionero en trascender el personaje de Cervantes del ámbito de la ilustración gráfica al de la pintura, permiten dar a conocer nuevas versiones sobre tabla de las ilustraciones para El Quijote que el artista británico realizó en la década de 1730 y nos aportan las inéditas representaciones de las estampas 18, 31, 32, 43 y 51, hasta ahora no documentadas entre las pinturas del artista. Además la que reproduce la estampa $\mathrm{n}^{\mathrm{o}} 21$, segunda versión de la conservada en la York Art Gallery, nos corrobora la existencia de, al menos, dos series de tablas quijotescas, una más fiel al planteamiento neoclásico original de las ilustraciones y otra más retórica, que Vanderbank destinaría a una clientela menos exigente y erudita.

La nueva lectura neoclásica, interpretada y representada visualmente a partir del cerrado programa diseñado por Vanderbank, supone el inicio de la mitificación icónica y cultural de El Quijote que comienza a consolidarse como referente literario y moral. Un nuevo criterio de lectura, que abrirá el camino a la interpretación simbólica de la obra y a la lectura romántica de la misma, que elevará al personaje al nivel de mito universal (Lucia, 2006: 162163). A partir del modelo inglés, desde finales del XVIII surgen nuevas e interesantes interpretaciones de los héroes y las aventuras quijotescas, entre las que destacan las propuestas de William Hogarth y del pintor y grabador alemán Daniel Nikolaus Chodowiecki (1726-1801) que, con preciosistas imágenes que muestran su gran capacidad para plasmar la ironía, la seriedad o la socarronería del texto, preceden a la exaltación romántica de la novela cervantina (Lucía, 2006: 470-483).

En el s. XIX el Romanticismo alemán recupera al Quijote con un signo original e, iniciando la crítica cervantista, autores como Schlegel, Hegel, Schelling, Heine o Richter, encumbran y difunden por toda Europa la interpretación simbólica de la obra como un referente mítico y atemporal. La recepción romántica del Quijote, como símbolo de la dualidad existencial humana, del conflicto universal entre realismo e idealismo, tendrá en Francia sus máximos exponentes en realistas como Balzac, Flaubert y Stendhal y, en España, convertido en paradigma del tradicionalismo de la cultura castellana y símbolo del orgullo nacionalista, será trascendental para noventayochistas, regeneracionistas y novecentistas como Azorín, Galdós, Unamuno y Ortega y Gasset (Close, 2005: 52-75). La progresiva implantación de los ideales románticos llevará consigo también el nacimiento de nuevos modelos de representación iconográfica del Quijote acordes con su nueva recepción. Este proceso que inicia Tony Johannot (1803-1852) con sus ilustraciones para la edición parisina de 1836, traducida por Louis Viardot, en las que incluye nuevos episodios de la novela y reinterpreta y adapta los ya existentes (González Moreno, 2009: 343-368), gozó de enorme éxito hasta la publicación en 
1863 del juego de estampas de Gustave Doré que, con su particular universo romántico, será el más copiado y difundido de la obra cervantina (Lucía Megías, 2005b).

Desde Vanderbank, que con su agudeza e intención contribuyó de un modo trascendental a fijar plásticamente los rasgos inconfundibles de los protagonistas y los episodios de la novela, el arte halló en el idealista y visionario Quijote una fuente inagotable de sugerentes motivos expresivos. En la segunda mitad del XIX, con el renovado interés por la pintura de género y de anécdotas históricas, pintores de toda Europa contribuirán al auge de su representación.

\section{BIBLIOGRAFÍA CITADA}

Ardila, J.A.G. (2005). «Traducción y recepción del "Quijote" en Gran Bretaña (16121774)», Anales Cervantinos, XXVII, pp. 253-265. Accesible en $<\mathrm{http}: / /$ analescervantinos.revistas.csic.es>

Astrana Marín, Luis (1948) [2003]. Vida ejemplar y heroica de Miguel de Cervantes Saavedra. Con mil documentos hasta ahora inéditos y numerosas ilustraciones y grabados de época, tomo 1. Madrid: Reus. Accesible en <http://www.biblioteca.org.ar/libros/89186.pdfs

Blas, Javier, Matilla, José Manuel (2003). «Imprenta e ideología. El Quijote de la Academia, 1773-1780», en Patrick Lenaghan (coord.), Imágenes del Quijote. Modelos de representación en las ediciones de los siglos XVII-XIX. Madrid: The Hispanic Society of America, Museo Nacional del Prado, Real Academia de Bellas Artes de San Fernando, Calcografía Nacional, pp. 73-117.

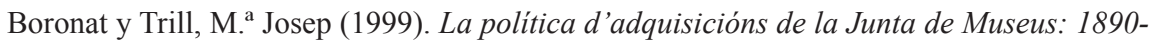
1923. Barcelona: Publicacions de L'Abadia de Montserrat, pp. 89, 92, 96-99,114, 201, 228-243, 261, 277, 357, 411.

Carmona Badía, Xoán (2006). «De Lugo a Capetón: a traxectoria empresarial do grupo Fernández» en Xoán Carmona Badía (coord.), Empresarios de Galicia. A Coruña: Caixagalicia, pp. 434-442.

Causey, Andrew (1967). «Don Quixote through a Painter's Eyes», Illustrated London News, 28 October, pp. 38-39.

Cervantes Saavedra, Miguel de: Vida y hechos del ingenioso hidalgo Don Quixote de la Mancha. London: J.\& R. Tonson, 1738. Imágenes de las estampas accesibles en $<\mathrm{http} / /$ www.qbi2005.com/wfrmMosaico.aspx?irc=3\&ircID=0111 $>$ y $<$ http:/www.csdl.tamu. edu:8080/dqiDisplayInterface/doSearchImages.jsp?id=1513\&page $=1 \&$ orderBy=1>

Cherry, Bridget, Pevsner, Nikolaus (2002). London 4: North. The buildings of England. Yale: University Press.

Close, Anthony (2005). La concepción romántica del «Quijote». Barcelona: Crítica.

Depauw, Carl, Luitjen, Ger (eds) (2003). Antón Van Dyck y el arte del grabado. Madrid: Fundación Carlos de Amberes.

De Ricci, Seymour (1930) [1960]: English Collectors of Books \& Manuscripts (1530-1930) and their marks of ownership). Cambridge: Cambridge University Press e Indiana University Press. Accesible en $<$ https://archive.org/stream/englishcollector00 ricc\#page/ n7/mode/2up> 
Díez, José Luis (ed.) (2003). Tres mitos españoles: La Celestina, Don Quijote, Don Juan. Madrid: Sociedad Estatal de Conmemoraciones Culturales.

Einberg, Elizabeth, Manners \& morals: Hogarth and British painting 1700-1760. London: Tate Gallery (1987).

Einberg, Elizabeth, Egerton, Judy (1988). The age of Hogarth: British Painters Born 16751709. London: Tate Gallery, II.

Fontaneda Berthet, Cristina, León López, Juan Alfonso (2005). La imagen del Quijote en la Corte Española del s. XVII. Miniaturas de la Colección Eugenio Fontaneda. Valladolid: Caja España.

García Felguera, M. ${ }^{a}$ de los Santos (2005). «Quijotes pintados en los siglos XVII y XVIII» en El Quijote desde el siglo XXI, Nicasio Salvador Miguel y Santiago López Ríos (ed.). Alcalá de Henares (Madrid): Centro de Estudios Cervantinos, pp. 155-171

González Moreno, Fernando, Urbina, Eduardo, Furuta, Richard y Deng, Jie (2005). «La colección de Quijotes ilustrados del Proyecto Cervantes: Catálogo de ediciones y archivo digital de imágenes», Cervantes: Bulletin of the Cervantes Society of America, 25.1 (2005), pp. 79-104. Accesible en <http://users.ipfw.edu/jehle/cervante/csa/ artics05/moreno.pdf>

González Moreno, Fernando (2009). «Don Quijote en los albores del Romanticismo o el prodigio ilustrado de Tony Johannot» en Hans Christian Hagerdorn (coord.) Don Quijote cosmopolita. Nuevos estudios sobre la recepción internacional de la novela cervantina. Cuenca: Ediciones de la Universidad de Castilla-La Mancha, pp. 343-368. Accesible en $<$ http:// books.google.es/books?id $=327 \mathrm{wAgAAQBAJ} \& p g=$ PA23\&lpg= PA23\&dq $=$ gonz $\% \mathrm{C} 3 \%$ A1lez+moreno $+\mathrm{y}+$ tony + johannot\&source $=$ bl\&ots $=$ WHi-4OJY I1\&sig=1i3dTa1qrBIZUKzm710jwyZQ74\&hl=es\&sa=X\&ei=HKJYVOUf8 JC xBLLT gpAF\&ved=0CBQQ6AEwAA $\# \mathrm{v}=$ onepage \&q=gonz $\% \mathrm{C} 3 \% \mathrm{~A} \quad 11 \mathrm{ez} \% 20$ moreno $\% 20$ $\mathrm{y} \% 20$ tony $\% 20$ johannot\&f $=$ false $>$

Hammelmann, Hanns Andreas (1968). «Eighteenth-Century English Illustrators: John Vanderbank 1694-1739», The Book Collector, XVII, pp. 289-293, 297-298.

Hammelmann, Hanns Andreas (1969). «John Vanderbank's “Don Quixote”», Master Drawings, 7-1, pp. 3-15.

Ingamells, John (1968), «John Vanderbank and Don Quixote», City of York Art Gallery Quarterly Preview, XXI, pp.763-767.

Krahe, Javier (2003), «Miscelánea gráfica cervantina en la Biblioteca del Cigarral del Carmen. Coypel, Vanderbank y Hogarth», en Patrick Lenaghan (coord.), Imágenes del Quijote. Modelos de representación en las ediciones de los siglos XVII-XIX. Madrid: The Hispanic Society of America, Museo Nacional del Prado, Real Academia de Bellas Artes de San Fernando, Calcografía Nacional, pp. 55-71.

Lenaghan, Patrick (coord.) (2003). Imágenes del Quijote. Modelos de representación en las ediciones de los siglos XVII-XIX, Madrid: The Hispanic Society of America, Museo Nacional del Prado, Real Academia de Bellas Artes de San Fernando, Calcografía Nacional.

Lenaghan, Patrick (2005). «'El regocijo de las musas’: la visión cómica del Quijote en los grabados del siglo XVIII-Prints» en Don Quijote: tapices españoles del siglo XVIII = 18th century spanish tapestries. Madrid: Ediciones El Viso: SEACEX, pp. 63-87

Lucía Megías, José Manuel (2005). Los primeros ilustradores del Quijote. Madrid: Ollero y Ramos, 2005, pp. 33-57, 112-113, 120-121, 175-215.

Lucía Megías, José Manuel (2005b): «Imágenes para un libro universal Don Quijote de la Mancha (1605-1905)» en Marta Torres Santo Domingo (coord.), Don Quijote en el campus: tesoros complutenses. Madrid: Biblioteca Histórica Marqués de Valdecilla, 
pp. 121-151. Accesible en <http://biblioteca.ucm.es/foa/exposiciones/15Quijote/ estudios.htm>

Lucía Megías, José Manuel (2006). Leer el Quijote en imágenes: hacia una teoría de los modelos iconográficos. Madrid: Calambur.

Luna, Juan J. (1989). «Pintura británica (1500-1800)» en Summa Artis, t. XXXIII, Madrid: Espasa Calpe, pp. 104-116.

March, Eva (2011). «1897-1912. Quince años de adquisiciones frustradas en el actual Museu Nacional d'Art de Catalunya: museo local vs. museo histórico» en Silvia Canalda, Carme Narváez, Joan Sureda (eds.), Cartografías visuales y arquitectónicas de la modernidad siglos XV-XVIII. Madrid: Edicions de la Universitat de Barcelona, pp.

Meixell, Amanda S. (2005). "Queen Caroline's Merlin Grotto and the 1738 Lord Carteret Edition of Don Quixote: the Matter of Britain and Spain's Arthurian Tradition», Cervantes: Bulletin of the Cervantes Society of American, 25, 2, pp. 59-82.

Oldfield, John (1738). «Advertencias de D. Juan Oldfield Doctor en Medicina sobre las estampas desta Historia» en Cervantes Saavedra, Miguel de, Vida y hechos del ingenioso hidalgo Don Quixote de la Mancha. Tomo I. Londres: J \& R Tonson, I-VIII. Accesible en $<$ http://alfama.sim.ucm.es/dioscorides /consulta_libro.asp?ref=B2082787 $8 \&$ idioma $=0 \mathrm{ld}+\mathrm{y}+$ advertencias $\& \mathrm{hl}=\mathrm{es} \& \mathrm{sa}=\mathrm{X} \& \mathrm{ei}=\mathrm{c} 6 \mathrm{p} Y$ VMOoIYXmaIu7grAP\&ved $=$ 0CD4Q6AEwBzgK\# $\mathrm{v}=$ onepage $\& \mathrm{q}=$ Oldfield $\% 20 \mathrm{y} \% 20$ advertencias $\& \mathrm{f}=$ false $>$

Paulson, Ronald, Hogarth (1992). The «modern moral subject», 1697-1732, Vol. I, Cambridge: The Lutterworth Press, pp. 204-205.

Paulson, Ronald (1998). Don Quixote in England: The Aesthetics of Laughter. Baltimore and London: The Johns Hopkins University Press, pp. 47-50.

Pierce Jr., Charles E. (1995). «Foreword» en Fletcher, H. George, In Praise of Aldus Mautius. A Quincentenary exhibition. New York: The Pierpont Morgan Library [Los Angeles: UCLA University Research Library, Department of Special Collections, 1995] pp. VII-VIII. Accesible en <https://archive.org/stream/inpraiseofaldusm00flet\# page/ n7/mode/2up>

Ruiz i Quesada, Francesc (2009-2011). «La incidencia de las fuentes escritas en la iconografía del retablo de Santo Domingo de Silos de Bartolomé Bermejo», Butlletí de la Reial Acadèmia Catalana de Belles Arts de Sant Jordi, XXIII-XXIV, pp.. Accesible en $<$ http://www.raco.cat/index.php/ButlletiRACBASJ/article/viewFile /242257/329481>

Salvador Miguel, Nicasio y López Ríos, Santiago (ed.) (2005). El Quijote desde el siglo XXI, Alcalá de Henares (Madrid), Centro de Estudios Cervantinos.

Schmidt, Rachel (1998). Critical Images: The Canonization of Don Quixote through Illustrated Editions of the Eighteenth Century. Montreal: McGill-Queen's University Press.

Tormo y Monzó, Elías (1926). Bartolomé Bermejo el más recio de los primitivos españoles, I. Madrid.

Torres Santo Domingo, Marta (coord.) (2005). Don Quijote en el campus: tesoros complutenses. Madrid: Biblioteca Histórica Marqués de Valdecilla, Accesible en $<\mathrm{http}$ ://biblioteca.ucm.es/foa/exposiciones/15Quijote/estudios.htm>

Urbina, Eduardo, Monroy, Carlos y Furuta, Richard (2003-2004). «Iconografía textual del Quijote: repaso y nueva aproximación de cara al IV centenario», Le mappe nascoste di Cervantes. Venecia: Actas Coloquio Internacional de la Associazione Cervantina di Venecia. Treviso: Edizioni Santi Quaranta. Accesible en <http://cervantes.tamu.edu/ pubs/UrbinaIconograf_a\%20textual\%20del\%20Quijote.pdf $>$

Vertue, George (1849). Anecdotes of painting in England: with some account of the principal artists, and incidental notes on other arts. Also, a catalogue of engravers who have been born or resided in England / collected by the late George Vertue; digested and published from his original mss. by Horace Walpole; with additions by... James 
Dallaway. London: H. G. Bohn. Accesible en $<$ http://babel.hathitrust.org/cgi/pt?id=ya le.39002029632974; view=1up;seq=7>

Vertue, George (1750, ed. 1934). Notebook, III. Oxford: The Walpole Society, XXII. Waterhouse, Ellis (1969). Painting in Britain, 1530-1790. London: Penguin Books.

Recibido: 11 de abril de 2014

Aceptado: 14 de noviembre de 2014

\title{
Resumen
}

En el Museo de Pontevedra destaca un conjunto de seis cuadros de pequeño formato que narran escenas de El Quijote. Realizados al óleo sobre tabla, son obra del pintor e ilustrador inglés John Vanderbank (1694-1739) que en ellos versiona algunas de las estampas que él mismo diseñó para ilustrar la edición de lujo de la novela de Miguel de Cervantes que, promovida por Lord Carteret e impresa por los hermanos Tonson, se realizó en Londres en 1738 .

Palabras clave: Quijote; iconografía; ilustración; pintura; grabado; John Carteret; John Vanderbank; Museo de Pontevedra

Title: Contribution to the Catalogue of the painter and illustrator John Vanderbank: Six new Oils with Scenes of The Quixote in the Museum of Pontevedra

\begin{abstract}
In the Museum of Pontevedra stands out a set of six pictures of small format that narrate scenes of the Quixote. Realized in oil on table, they are works of the Englishman painter and illustrator John Vanderbank (1694-1739). In those pictures he adapts some of the prints that himself designed to illustrate the edition of luxury of Miguel de Cervantes who, promoted by Lord Carteret and printed by the Tonson brothers, was realized in London in 1738 .
\end{abstract}

Key words: Quixote; iconography; illustration; painting; engraving; John Carteret; John Vanderbank; Museum of Pontevedra. 